Article

\title{
Life Cycle Assessment of a Combined-Cycle Gas Turbine with a Focus on the Chemicals Used in Water Conditioning
}

\author{
Catalina Ferat Toscano ${ }^{1, *}$, Cecilia Martin-del-Campo ${ }^{1}$, Gabriela Moeller-Chavez ${ }^{2}$, \\ Gabriel Leon de los Santos ${ }^{1}$, Juan-Luis François ${ }^{1}$ and Daniel Revollo Fernandez ${ }^{3}$ \\ 1 Facultad de Ingeniería, Universidad Nacional Autónoma de México, Av. Universidad 3000, \\ 04510 Ciudad de México, Mexico; cecilia.martin.del.campo@gmail.com (C.M.-d.-C.); \\ tesgleon@yahoo.com (G.L.d.l.S); juan.luis.francois@gmail.com (J.-L.F.) \\ 2 Dirección de Ingeniería Ambiental y Biotecnología. Universidad Politécnica del Estado de Morelos, \\ Paseo Cuauhnáhuac No. 566, 62550 Jiutepec, Morelos, Mexico; gabriela.moeller@gmail.com \\ 3 CONACYT-Universidad Autónoma Metropolitana, Unidad Azcapotzalco, Av. San Pablo No. 180, \\ 02200 Ciudad de México, Mexico; drevollofer@gmail.com \\ * Correspondence: cferat@unam.mx; Tel.: +52-555-622-3002
}

Received: 10 April 2019; Accepted: 15 May 2019; Published: 22 May 2019

\begin{abstract}
Life Cycle Assessments (LCAs) of thermoelectric plants frequently focus on impacts related to fuel and water consumption. The purpose of this research was to determine the environmental impact of the chemicals used for water conditioning in a Combined-Cycle Gas Turbine (CCGT) plant in Mexico. An LCA of the electricity generation process was carried out using the SimaPro software with the ReCiPe method, which includes 18 midpoint environmental impact categories. The process was broken down into stages, which were analyzed separately. To complete the study, an analysis of the fuel cycle and the materials used for maintenance works were included. Results showed that the most affected impact categories were water depletion $\left(9.77 \times 10^{-1} \mathrm{~m}^{3} / \mathrm{MWh}\right)$, due mainly to the high volume of water consumption in the cooling systems and the reverse osmosis process; freshwater, marine, and terrestrial ecotoxicity $\left(1.59 \times 10^{-2} \mathrm{~kg} 1,4-\mathrm{DB}\right.$ eq/MWh $)$, and human toxicity $\left(1.1 \times 10^{-1} \mathrm{~kg} 1,4-\mathrm{DB}\right.$ eq/MWh$)$ - due to the production and consumption of the chemicals used. One such chemical is hydrazine, which is a highly toxic compound to humans and other living organisms. It is worth mentioning that traces of some chemicals in wastewater discharges could be considered as emerging pollutants because of their potential health hazards, which have not been reported yet.
\end{abstract}

Keywords: water quality; life cycle assessment; emerging pollutants; combined-cycle gas turbine; chemical compounds; hydrazine; electric power generation

\section{Introduction}

Water is essential to maintaining life on Earth, and it is also a key resource for electricity generation. It is expected that worldwide water demand will double by 2050 due to population growth and the improvement of living standards [1].

The water-energy nexus has a significant influence on a country's energy development. The amount of water required for electricity generation depends on the capacity of the plant, the power generation technology, and the availability and location of water sources. Electricity generation has a potential impact on the quantity and quality of available water [2].

In Mexico, according to the National Water Commission [3], by the end of 2016, the volume of water allocated for offstream use was $85,664 \mathrm{Mm}^{3}$, of which $4149 \mathrm{Mm}^{3}$ was used for thermoelectric plants. 
Energy consumption is expected to grow at an average annual rate of 3.1\% between 2018 and 2032, that is, from 320,629 GWh (2018) to 492,165 GWh (2032), which represents an increase of 53.5\% $(171,536 \mathrm{GWh})$. This future demand will be satisfied with new plants-an added capacity of 66,912 MW, of which $42 \%(28,105 \mathrm{MW})$ will be generated by combined-cycle technology [4].

Combined-cycle gas turbine (CCGT) plants use two technologies: a steam turbine cycle (conventional thermoelectric) and a gas turbine cycle (turbo gas), resulting in higher efficiency-close to $59 \%$ at full load compared to conventional systems, whose efficiencies range between $32 \%$ and $39 \%$. For this reason, the amount of $\mathrm{CO}_{2}$ emitted per $\mathrm{kWh}$ of electricity generated is nearly $40 \%$ lower than that emitted by other types of power stations that use fossil fuels. Emissions of sulfur dioxide $\left(\mathrm{SO}_{2}\right)$, nitrogen oxides $\left(\mathrm{NO}_{\mathrm{x}}\right)$, and solid particles are very low and, in some cases, negligible. Therefore, CCGT plants have lower electricity generation costs and cause less environmental pollution compared to plants that use only one technology [5]. Furthermore, their construction time is relatively short because they can be installed by modules - the gas turbine first and the steam turbine later-increasing their operational flexibility. Due to their characteristics, these technologies are becoming widespread in the Mexican electricity sector [6].

On the other hand, CCGT plants use chemicals (some of them toxic) throughout the different stages of the electricity generation process. These materials are released into the environment as atmospheric emissions or wastewater discharges, with impacts on natural resources, air, soil, and water [5].

Chemical contamination of water resources has serious implications on aquatic ecosystems. These effects range from eutrophication - which can lead to oxygen depletion in water, killing fish and other aquatic populations-to health problems such as cancers, reproductive disorders, damage to cellular structures and DNA, and malformations. Furthermore, adverse effects on aquatic microorganisms can have a ripple effect throughout all levels of the food chain. Chemicals that accumulate in aquatic organisms bioconcentrate in other animals that feed on these organisms [7].

In the United States of America, some environmental studies on steam turbine plants identified large amounts of toxic pollutants discharged into surface water sources. Most of these toxic pollutants—which include arsenic, lead, mercury, selenium, chrome, and cadmium-remain in the environment for many years. This concern led the Environmental Protection Agency (EPA) to establish federal limits on the levels of toxic metals in wastewater discharged from power plants to preserve environmental and public health conditions. These regulations were included in the EPA 2015 Final Rule [8]. In Mexico, the Mexican Official Norm NOM-001-SEMARNAT-1996 [9] establishes the maximum permissible limits of pollutants in wastewater discharged into national waters and resources.

However, there are chemicals—known as emerging pollutants—that are not currently regulated and could have a negative effect on health. Their occurrence on the environment, risk contribution, and ecotoxicological effects are often unknown. Emerging pollutants may be candidates for future regulation, depending on the results of ongoing studies on their potential effects on health and the incidence monitoring data [10].

A powerful tool for evaluating environmental impacts is the life cycle assessment (LCA) methodology. This technique identifies and quantifies the energy and material inputs as well as environmental releases associated with all the stages of the life cycle of a product or service-from raw material extraction to disposal or recycling [11].

In our review of the literature on LCAs of electricity generation systems, we found that most of the studies evaluate the environmental impact by focusing on the use of different types of fossil fuels and/or by comparing alternative technologies [12-16].

Some of these studies have only focused on natural gas [17]. Others such as that of Spath and Mann [18] are more comprehensive. They conducted an LCA of a natural gas combined-cycle system to identify its environmental advantages and disadvantages, and their scope included the fuel life cycle, from extraction and transportation to plant construction, operation, and dismantling. 
Agrawal et al. [15] carried out an LCA on a CCGT plant to identify the midpoint (problem-oriented) and endpoint (damage-oriented) impacts. The LCA included the processes within the power plant boundary (electricity, water usage, natural gas combustion, wastewater disposal, etc.), and it also considered upstream processes, such as extraction, natural gas processing, and transportation.

All of these studies focused on fossil fuel consumption and considered upstream and downstream processes. Furthermore, the electricity generation process-which involves water conditioning, the water-steam cycle, and the cooling system-is seen as a whole, without getting into details about its internal functioning.

Mertens et al. [19], on the other hand, determined the water footprint of CCGTs and, by analyzing different cooling systems, looked at each stage of the electricity generation process separately. The authors applied three different methodologies and took as criteria the type of fuels, the water used in the demineralization process, and the cooling technologies employed-aero condensation, cooling towers with surface raw water and seawater, and open circuit.

The results reported in most of the articles analyzed suggest that environmental impacts are caused mainly by the high consumption of fossil fuels and the effects of their combustion and upstream processes-extraction, processing, and transportation.

However, to our knowledge, no previous study has investigated the effects of the chemicals used for water conditioning in a CCGT plant.

To determine the environmental impact of the chemicals used for water conditioning in a CCGT plant, an LCA of the electricity generation process was carried out. The process was broken down into stages, which were analyzed separately. An analysis of the fuel cycle and the materials used for maintenance works was also carried out to complete the study.

Our results showed that the most affected categories were related to air, water, and toxicity to the environment and living organisms. These impacts were mainly caused by the amount of natural gas, the volume of water extracted, and the manufacture and consumption of the chemicals used in the process.

The rest of this paper is organized into three sections. Section 2 describes the methodological approach taken in this study; this section also includes the criteria that was used to interpret the results. Section 3 presents the results of the LCA, focusing on contribution and sensitivity analyses. Finally, Section 4 provides a summary of the findings, comments on the limitations of the study, and suggests areas for further research. A list of the acronyms, initialisms, and chemical symbols used throughout this paper is included in Appendix A.

\section{Materials and Methods}

The LCA methodology includes four phases: (1) Goal and scope, (2) Life cycle inventory analysis (LCI), (3) Life cycle impact assessment (LCIA), and (4) Results and interpretation. Mexican Guidelines NMX-SAA-14040-IMNC-2008 [20] and NMX-SAA-14044-IMNC-2008 [21], which are equivalent to ISO 14040:2006 and ISO 14044:2006, respectively, support this methodology.

\subsection{Goal, Scope, and Functional Unit}

As stated in the introduction, the aim of this study was to determine the environmental impact of the chemicals used for water conditioning during the power generation process in a CCGT plant. The study was carried out in a CCGT plant located in Central Mexico. The reports on water usage from December 2014 to October 2015 were examined, and the data from December-the month with the highest level of water usage recorded-was selected for the study.

The functional unit was set to $1 \mathrm{MWh}$ of electricity produced by the CCGT plant, and it was used as a reference unit to quantify all the inputs (materials) and outputs (emissions and discharges). 


\subsubsection{System Description}

CCGT power plants use two thermodynamic cycles to generate electric power. A gas turbine-operating on a Brayton cycle-burns natural gas, and the resulting combustion exhaust gases power a generator to produce electricity. Waste heat in the exhaust gases is captured and routed to a heat recovery steam generator (HRSG), which heats water to produce steam that powers the steam turbine (Rankine cycle), generating more electricity. Surplus steam is then transformed into water in a condenser for its recycling in the HRSG.

Two types of water quality are used in this process: demineralized water-which circulates through the HRSG and condenser (water-steam cycle)—and well water, which circulates through the condenser and cooling tower (cooling system).

To maintain operational conditions at an optimum level and avoid corrosion, fouling, and scaling problems, a good chemical treatment control (water conditioning) is necessary to modify the physicochemical characteristics of water and adapt them to the predefined and desired parameters for the electricity generation process [5].

To define the subprocesses that would be included in the LCA, a block diagram that illustrates the electricity generation process was designed (see Figure 1). The subprocesses where chemicals for water conditioning are used comprise the demineralized water treatment plants, the cooling system, and the water-steam cycle. The fuel cycle includes natural gas processing and transportation, extraction, and combustion. Maintenance works comprise the materials used for plant maintenance.

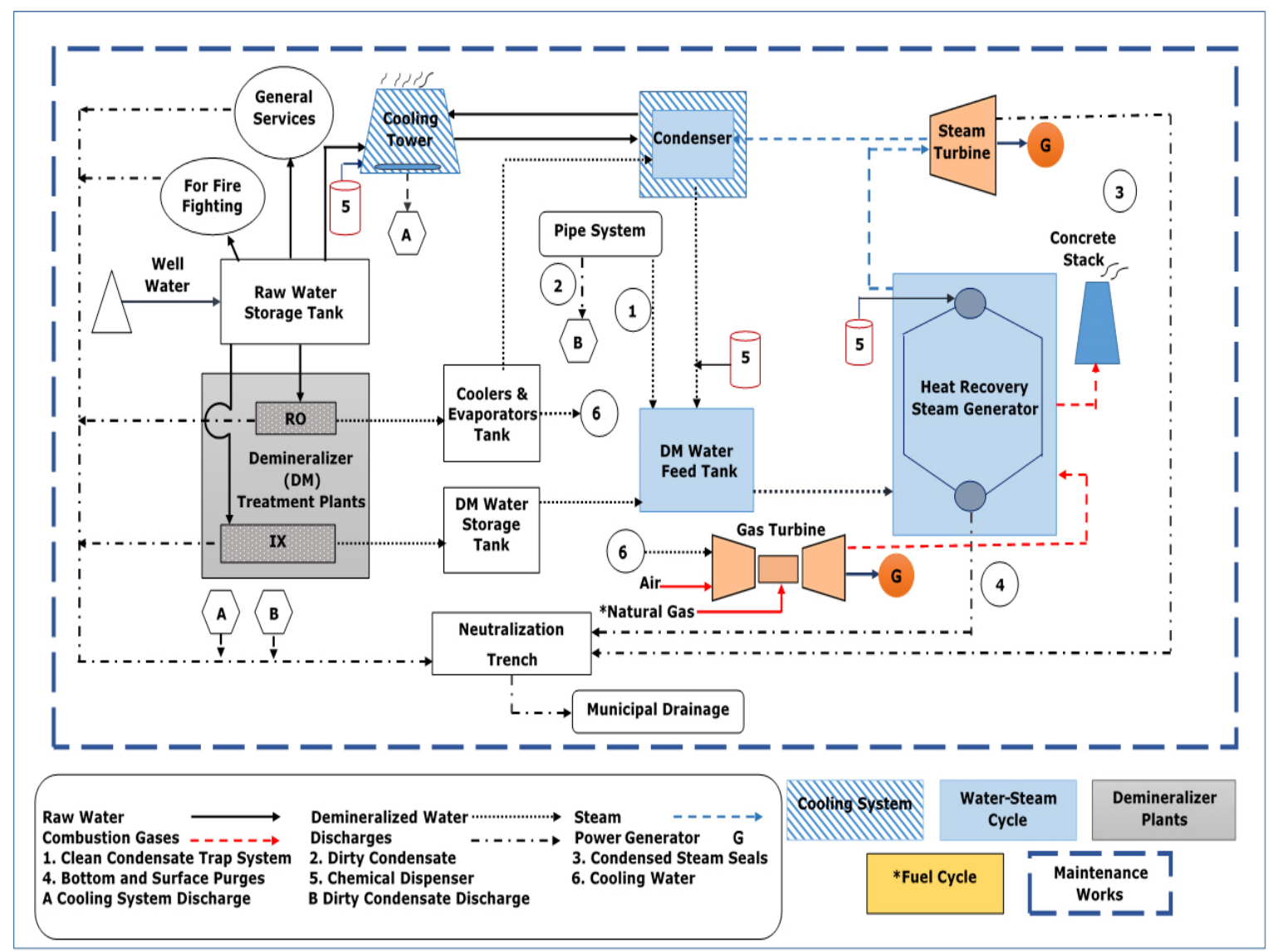

Figure 1. Block diagram of the electricity generation process in the Combine-Cycle Gas Turbine (CCGT) plant. 
Demineralizer Treatment Plant

Water conditioning is carried out in two demineralizer treatment plants: reverse osmosis (RO) and ion exchange (IX).

Intake water coming from a well is treated in the RO plant to eliminate salts, organic compounds, and microorganisms through membranes that are made of polymeric materials (polyamide). It is necessary to pretreat water with phosphonates to avoid membrane fouling. Water coming through the membranes is posttreated in an ion-exchange mixed bed as a polishing treatment to improve its quality.

IX is the reversible exchange of ions between a solid (ion-exchange material or resin) and a liquid. In the IX process, resins remove almost all cations and anions from the water. The efficiency of the process is determined by the composition of the water supply, the types and quantities of the resins used, and the resin regeneration process, among other factors.

The IX process is done sequentially (in a three-filter train): first, the water goes through a cationic resin, then through an anionic resin, and, finally, through a mixture of cationic and anionic (mixed bed) resins. The IX process is reversible, and the direction of the reaction depends on the ion concentration and the resin saturation level. Once the resins are saturated, they undergo a regeneration process.

The CCGT plant of our case study uses two three-filter trains. While one is working, the other regenerates. The cationic resin is regenerated with sulfuric acid $\left(\mathrm{H}_{2} \mathrm{SO}_{4}\right)$, and the anionic resin uses a sodium hydroxide $(\mathrm{NaOH})$ solution in demineralized water.

\section{Water-Steam Cycle}

Water treatment in the water-steam cycle is treated with several chemicals: phosphates for $\mathrm{pH}$ control, which regulate the steam and liquid phases; cyclohexylamine, to avoid corrosion; and hydrazine, which is used to eliminate the remaining oxygen dissolved in the liquid and steam phases. In addition, a purge regime is necessary to control salt concentration [5].

\section{Cooling System}

Cold well water from the cooling tower is used for steam condensation in the condenser. There is a continuous flow of water between the condenser and the cooling tower, where there could be substantial water loss due to evaporation, leaks, and purges [5]; in these cases, make-up water is continuously fed to the cooling tower.

Water treatment in this circuit is applied to simultaneously control corrosion, inorganic scaling deposition, fouling, and the growth of microorganisms. Sodium hypochlorite $(\mathrm{NaClO})$ is added as a biocide for microbiological control; bio-dispersants, such as orange terpenes, are used to improve the efficiency of the biocides [22]; copper inhibitors, such as sodium salt of tolyltriazole and hydroxyphosphonoacetic acid (HPAA), are added to protect the facilities from scaling and metal corrosion.

The higher the $\mathrm{pH}$ in the cooling water, the lower the effectiveness of the chemical pretreatment. Therefore, it is necessary to lower the $\mathrm{pH}$ level by adding $\mathrm{H}_{2} \mathrm{SO}_{4}$.

\subsubsection{System Boundaries}

The system boundaries defined for the LCA are the following:

- Upstream operations: extraction, processing, and transportation of fuel (natural gas), and manufacture of some of the input materials used in the main subprocesses (see Section 2.2. Life Cycle Inventory).

- Downstream operations: wastewater discharges and solid waste treatment and disposal

- Main subprocesses and activities:

natural gas combustion 
water demineralization, which is carried out by RO and IX treatments

water-steam cycle, which comprises the HRSG and water condenser

cooling system, which is composed of the cooling tower and the condenser

maintenance work activities, including water consumption for general services and the fire-fighting system

The scope of this research was from cradle to gate [23]. Therefore, transmission, distribution, and consumption of electricity, as well as plant construction and decommissioning are outside the system boundaries.

Throughout this paper, the term "stages" will be used to refer to the subprocesses, activities, and operations that will be analyzed in the LCA. These are RO, IX, cooling system, water-steam cycle, maintenance works, and fuel cycle-which comprises natural gas extraction, processing, transportation to the CCGT plant, and combustion.

\subsection{Life Cycle Inventory}

\subsubsection{Considerations}

Operating conditions of the CCGT plant in our case study were the following:

- The fuel is natural gas.

- The electricity generation process is carried out in a combined-cycle unit using both a gas and a steam turbine.

- Demineralized water is produced by two treatment systems: RO and IX. The effluents from the RO and IX systems are used in the cooling system and the water-steam cycle, respectively. Membrane production for the RO process is not considered.

- The plant factor - or the ratio of the average power load of a plant to its rated capacity-is $100 \%$.

- The water supply is well water, and no pretreatment is required.

- The analysis is based on the gross power.

Table 1 describes the operating conditions of the plant; Table 2, the composition of the natural gas used as fuel.

Table 1. Combined-Cycle Gas Turbine (CCGT) plant characteristics.

\begin{tabular}{ccc}
\hline Operating Conditions & Amount & Unit \\
\hline Gross power & 196.21 & $\mathrm{MW}$ \\
Gross efficiency & 52.67 & $\%$ \\
Gross heat rate & 7041 & $\mathrm{~kJ} / \mathrm{kWh}$ \\
Net heat rate & 6836 & $\mathrm{~kJ} / \mathrm{kWh}$ \\
Daily natural gas consumption & $1,076,046$ & $\mathrm{~m}^{3} / \mathrm{day}$ \\
Own uses & 2.92 & $\%$ \\
Monthly electricity produced & $141,271.2$ & $\mathrm{MWh} / \mathrm{month}$ \\
Life time & 25 & years \\
\hline
\end{tabular}

Table 2. Natural gas composition.

\begin{tabular}{ccc}
\hline Element/Compound & Symbol & Volume \% \\
\hline Hydrogen & $\mathrm{H}_{2}$ & 0.36 \\
Oxygen & $\mathrm{O}_{2}$ & 0.07 \\
Nitrogen & $\mathrm{N}_{2}$ & 3.61 \\
Carbon Monoxide & $\mathrm{CO}$ & 0.09 \\
Carbon Dioxide & $\mathrm{CO}_{2}$ & 0.34 \\
\hline
\end{tabular}


Table 2. Cont.

\begin{tabular}{ccc}
\hline Element/Compound & Symbol & Volume \% \\
\hline Methane & $\mathrm{CH}_{4}$ & 87.0 \\
Ethane & $\mathrm{C}_{2} \mathrm{H}_{6}$ & 8.46 \\
Ethylene & $\mathrm{C}_{2} \mathrm{H}_{4}$ & 0.03 \\
Hydrogen Sulfide & $\mathrm{H}_{2} \mathrm{~S}$ & 0.04 \\
Total & & 100 \\
\hline
\end{tabular}

Fuel: Initial temperature of $25^{\circ} \mathrm{C}$.

\subsubsection{Data Collection}

Foreground data related to energy production-such as operating conditions, fuel combustion, chemical consumption, raw water intake, and wastewater discharges-were obtained from technical reports and specialized documents issued by the plant personnel.

Background data, not related to energy production-such as raw materials/compounds used for the production of chemicals (e.g., additives), gas extraction, and fuel processing and transportation - were obtained from the Ecoinvent database v.3.1.

In this database, the only country-specific data available for Mexico were related to energy and water resources. Therefore, data for chemical production and raw materials were taken from the Rest-of-the-World (RoW) dataset; transportation data, from the Europe (RER) dataset; and other chemicals not found in RoW were obtained from the Global (GLO) dataset.

There were other specific organic and inorganic compounds that could not be found in Ecoinvent. To fill this data gap, the "chemical production, organic" and "chemical production, inorganic" processes were selected. The considerations behind this selection were the following:

1. Human and environmental exposure to chemicals can occur at each stage of the chemical life cycle, including raw material extraction and chemical manufacturing [7].

2. Evaluating the impact of producing chemical compounds could provide some insight into the type of impact that these substances may have on the environment.

3. Information on chemical production is available in Ecoinvent.

Even though the inventories for the "chemical production, organic" and "chemical production, inorganic" datasets are based on literature and represent a rough approximation [24], the assessment results would reflect the potential impact of producing a chemical compound.

The limitation in using data that are not specific for Mexico is that they provide approximate results in the impact evaluation.

The allocation of the materials was performed according to the mass of the substances involved in the process. Low-consumption materials were excluded, except for hydrazine, which, despite its low consumption $\left(0.04 \mathrm{~m}^{3} /\right.$ month, at $\left.35 \%\right)$, it is extremely toxic [25] and thus was included. A $1 \%$ cut-off criteria - or the amount of matter flow associated with the unitary processes excluded from the calculation in the study [21] — was considered for the evaluation.

Atmospheric emissions from natural gas combustion-such as $\mathrm{SO}_{2}, \mathrm{CO}_{2}, \mathrm{NO}_{x}$, and $\mathrm{CH}_{4}$-were calculated according to the EPA emission factors [26] and were compared with the energy and mass balance results obtained from the Thermoflex software [27]. Technical documents from other plants using a similar technology were consulted to obtain data on materials used for maintenance work and waste disposal [28-30]. Input and output data inventory are presented in Figure 2 and correspond to the main stages depicted in Figure 1. 


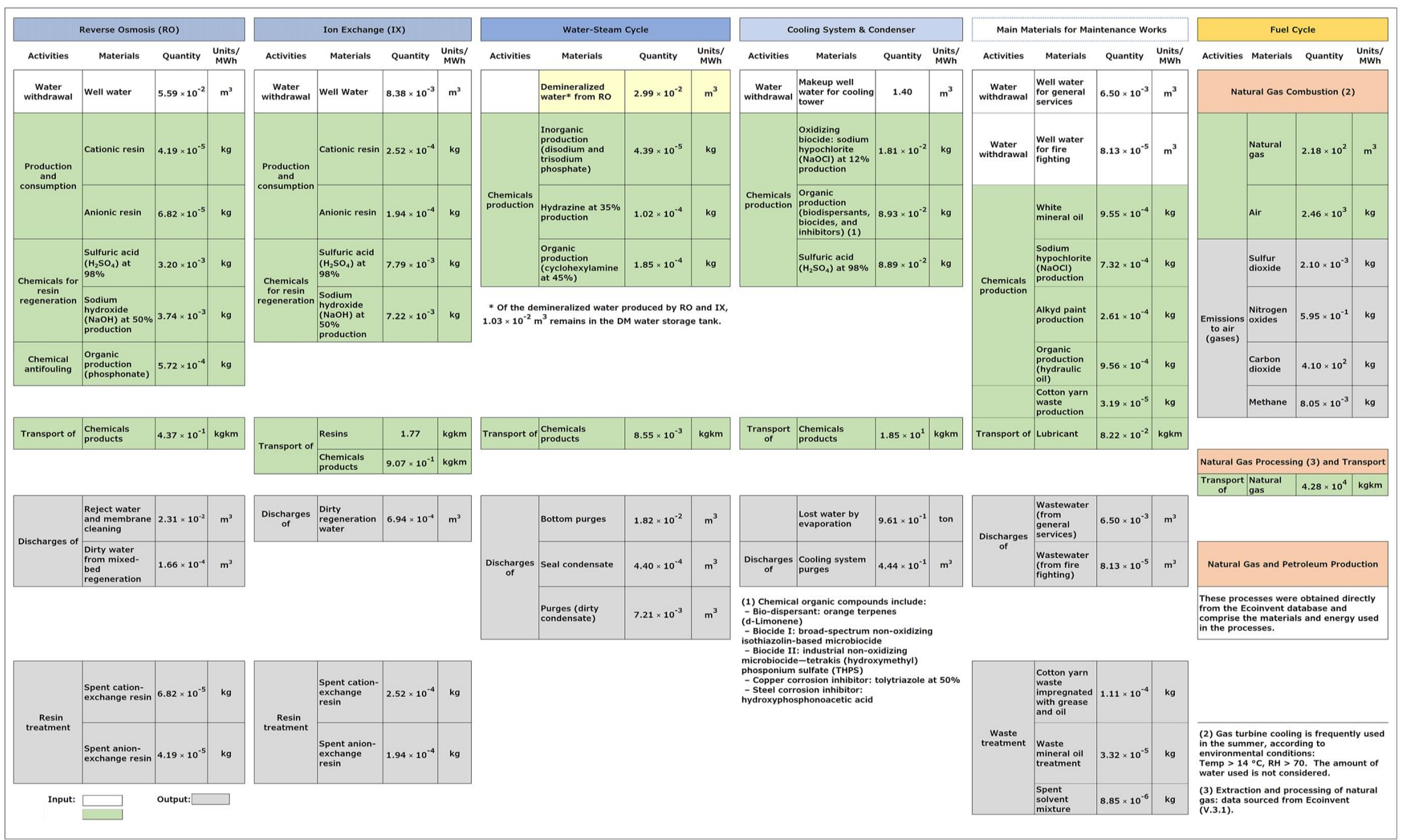

Figure 2. Input and output data inventory. 


\subsubsection{Assumptions}

The following assumptions were made:

- The resins are imported from the United States.

- The disposal of spent ion-exchange resins is done through municipal incineration.

- The materials are adapted to the conditions of Mexico's electricity mix.

- Demineralized water vapor is not considered in the water-steam cycle.

- Hazardous waste from the maintenance works was incinerated.

- The materials used are brought from nearby cities.

- Natural gas is transported from the Gulf of Mexico.

\subsection{Life Cycle Impact Assessment}

The LCA modeling was carried out using SimaPro 8.0.4.30 software [31]. The evaluation was performed with the ReCiPe method [32], employing 18 impact categories at the midpoint level (problem-oriented approach, such as acidification, climate change, and ecotoxicity) [33], applying the hierarchist perspective, and using the normalized world value (Europe excluded). It complies with ISO 14040 and 14044 standards and contains the broadest set of midpoint categories, whose factors, characterization models, and indicators are adequate to determine the environmental impact of electricity generation.

A detailed explanation of the impact categories is shown in Table $3[32,33]$.

Table 3. Impact categories according to the ReCiPe method.

\begin{tabular}{|c|c|c|c|}
\hline Impact Category Name & Unit & Description & Acronym \\
\hline Climate change & $\mathrm{kg} \mathrm{CO}_{2} \mathrm{eq}$ & $\begin{array}{l}\text { Increase in the temperature in the atmosphere by the emission of } \\
\text { greenhouse gases such as } \mathrm{CO}_{2}, \mathrm{CH}_{4}, \mathrm{~N}_{2} \mathrm{O}, \mathrm{HFC}, \mathrm{PFC} \text {, among others. }\end{array}$ & $\mathrm{CC}$ \\
\hline Ozone depletion & kg CFC-11 eq & $\begin{array}{l}\text { Ozone layer depletion by emission of anthropogenic substances, such } \\
\text { as chlorofluorocarbons (CFCs). }\end{array}$ & OD \\
\hline Terrestrial acidification & $\mathrm{kg} \mathrm{SO}_{2} \mathrm{eq}$ & $\begin{array}{l}\text { Inorganic acids released into the atmosphere-such as sulfates, nitrates, } \\
\text { and phosphates-which cause changes in the acidity of the soil. }\end{array}$ & TA \\
\hline $\begin{array}{c}\text { Freshwater } \\
\text { eutrophication }\end{array}$ & $\mathrm{kg}$ P eq & \multirow{2}{*}{$\begin{array}{l}\text { Accumulation of nutrients (nitrogen, phosphorus, or other carbon } \\
\text { compounds) in water overstimulate plant growth, which reduces the level } \\
\qquad \text { of } \mathrm{O}_{2} \text {. }\end{array}$} & $\mathrm{FE}$ \\
\hline Marine eutrophication & $\mathrm{kg} \mathrm{N} \mathrm{eq}$ & & ME \\
\hline Human toxicity & $\mathrm{kg} 1,4 \mathrm{DB}$ eq & \multirow{4}{*}{$\begin{array}{c}\text { Many industries use hazardous substances that are dangerous or toxic to } \\
\text { people and/or ecosystems. Health impacts depend on each substance, } \\
\text { the exposure route, the dose received, and the health conditions of } \\
\text { the exposed person, among other factors. }\end{array}$} & HT \\
\hline Terrestrial ecotoxicity & $\mathrm{kg} 1,4 \mathrm{DB}$ eq & & TET \\
\hline Freshwater ecotoxicity & $\mathrm{kg} 1,4 \mathrm{DB}$ eq & & FET \\
\hline Marine ecotoxicity & $\mathrm{kg} 1,4 \mathrm{DB}$ eq & & MET \\
\hline $\begin{array}{l}\text { Photochemical oxidant } \\
\text { formation }\end{array}$ & kg NMVOC & $\begin{array}{c}\text { Under the influence of solar radiation, nitrogen oxides }\left(\mathrm{NO}_{x}\right) \text { react with } \\
\text { volatile organic compounds }(\mathrm{VOC}) \text { to produce tropospheric ozone, } \\
\text { which causes climate change. }\end{array}$ & POF \\
\hline $\begin{array}{l}\text { Particulate matter } \\
\text { formation }\end{array}$ & $\mathrm{kg} \mathrm{PM}_{10}$ eq & $\begin{array}{l}\text { Very small (less than } 10 \text { microns in diameter) particulate matter of organic } \\
\text { and inorganic substances affects the respiratory tract and lungs } \\
\text { when inhaled. }\end{array}$ & PMF \\
\hline Ionizing radiation & $\mathrm{kBq} \mathrm{U}_{235} \mathrm{eq}$ & $\begin{array}{l}\text { Emission of radioactive material to the environment causes health effects, } \\
\text { depending on the level of exposure. }\end{array}$ & IR \\
\hline $\begin{array}{l}\text { Agricultural land } \\
\text { occupation* }\end{array}$ & $\mathrm{m}^{2} \mathrm{xyr}$ & \multirow{2}{*}{$\begin{array}{l}\text { Biodiversity depends on the size of the area and land use. Fauna and flora } \\
\text { are affected by land occupation. The unit used refers to occupied or } \\
\text { transformed area per unit of time. }\end{array}$} & ALO \\
\hline Urban land occupation* & $\mathrm{m}^{2} \mathrm{xyr}$ & & ULO \\
\hline $\begin{array}{l}\text { Natural land } \\
\text { transformation }\end{array}$ & $\mathrm{m}^{2}$ & $\begin{array}{l}\text { Land transformation or natural areas that have a high human intervention, } \\
\text { such as urban and agricultural land. }\end{array}$ & NLT \\
\hline Water depletion & $\mathrm{m}^{3}$ & Quantity of water used. & WD \\
\hline Mineral depletion & $\mathrm{kg} \mathrm{Fe} \mathrm{eq}$ & $\begin{array}{l}\text { Minerals are natural substances with specific chemical compositions that } \\
\text { are produced via geological processes. }\end{array}$ & MD \\
\hline Fossil fuel depletion & kg oil eq & $\begin{array}{l}\text { Depletion of resources that contain hydrocarbons-e.g., volatile materials } \\
\text { (methane, gasoline) and non-volatile materials (anthracite coal). }\end{array}$ & FD \\
\hline
\end{tabular}

* In SimaPro 8.0.4.30 the unit used is $\mathrm{m}^{2} \mathrm{a}$. 


\subsection{Interpretation of the Results}

\subsubsection{Contribution Analysis}

To get a detailed interpretation of the environmental impacts caused by each stage and find out which material has the highest contribution to each category, the stages were modeled separately considering their associated activities/materials (see Figure 2 of Section 2.2.2).

The results showed that all the activities/materials contribute to each impact category to a greater or lesser degree. For each impact category, the activity/material with the highest contribution was selected. Then, the compounds and substances associated with said activity or used in the production of said material were analyzed to identify the one responsible for the highest contribution to each category.

One way to make an interpretation of the category indicators is to normalize them. Normalization is a technique for changing impact indicator values with different units into a common, unitless format by dividing the values by a selected reference quantity. This process increases the comparability of data among various impact categories [34]. Normalized results were obtained directly by SimaPro using the World ReCiPe Midpoint $(\mathrm{H})$ normalization factor.

To analyze the relevance of the contributions of the processes and materials of each stage to each impact category, the following percentage contribution scale was proposed: (a) low contribution is less than $20 \%$, (b) medium-low, from $21 \%$ to $50 \%$, (c) high-medium, from $51 \%$ to $80 \%$, and (d) high, from $81 \%$ to $100 \%$.

In the following section (Results and Discussion), Figures 3a, 4a, 5a, 6a, 7a and 8a show the characterization results, and Figures $3 b, 4 b, 5 b, 6 b, 7 b$ and $8 b$ show the normalized results.

\subsubsection{Sensitivity Analysis}

Sensitivity analysis is a systematic procedure for the evaluation of the results in case there were changes in the process variables [20]. Based on the stages where chemicals are added and the operating conditions at other plants, three scenarios were developed to identify the potential impact of the chemicals used. The first two are related to changes in the operating conditions; the last one considers the presence of d-Limonene, an emerging pollutant, in the wastewater discharge:

- Scenario 1: Changing the water treatment process to produce demineralized water.

- Scenario 2: Using only hydrazine to prevent corrosion and control the $\mathrm{pH}$ level in the boiler feedwater treatment during the water-steam cycle.

- Scenario 3: Presence of d-Limonene in the water discharged from the cooling tower.

\section{Results and Discussion}

\subsection{Contribution Analysis Results}

Table 4 shows the individual contribution of each one of the stages to the different impact categories. These values were obtained by adding the contribution that the activities/materials associated with each stage made to the impact categories. The 18 midpoint impact categories are grouped according to the type of effect on the environment.

From the data in the table above, it is apparent that there is a wide variation between the contribution of the fuel cycle and that of the other stages. The amount of natural gas consumed $\left(218 \mathrm{~m}^{3} / \mathrm{MWh}\right)$ in the fuel-cycle process is higher than that of other materials consumed in the other processes (see Figure 2). For this reason, the fuel cycle has the highest contribution, which overshadows the contribution of the other stages to the impact categories, as Figure 3a,b illustrate. 
Table 4. Life Cycle Assessment (LCA) results: impact categories grouped by type of environmental impact.

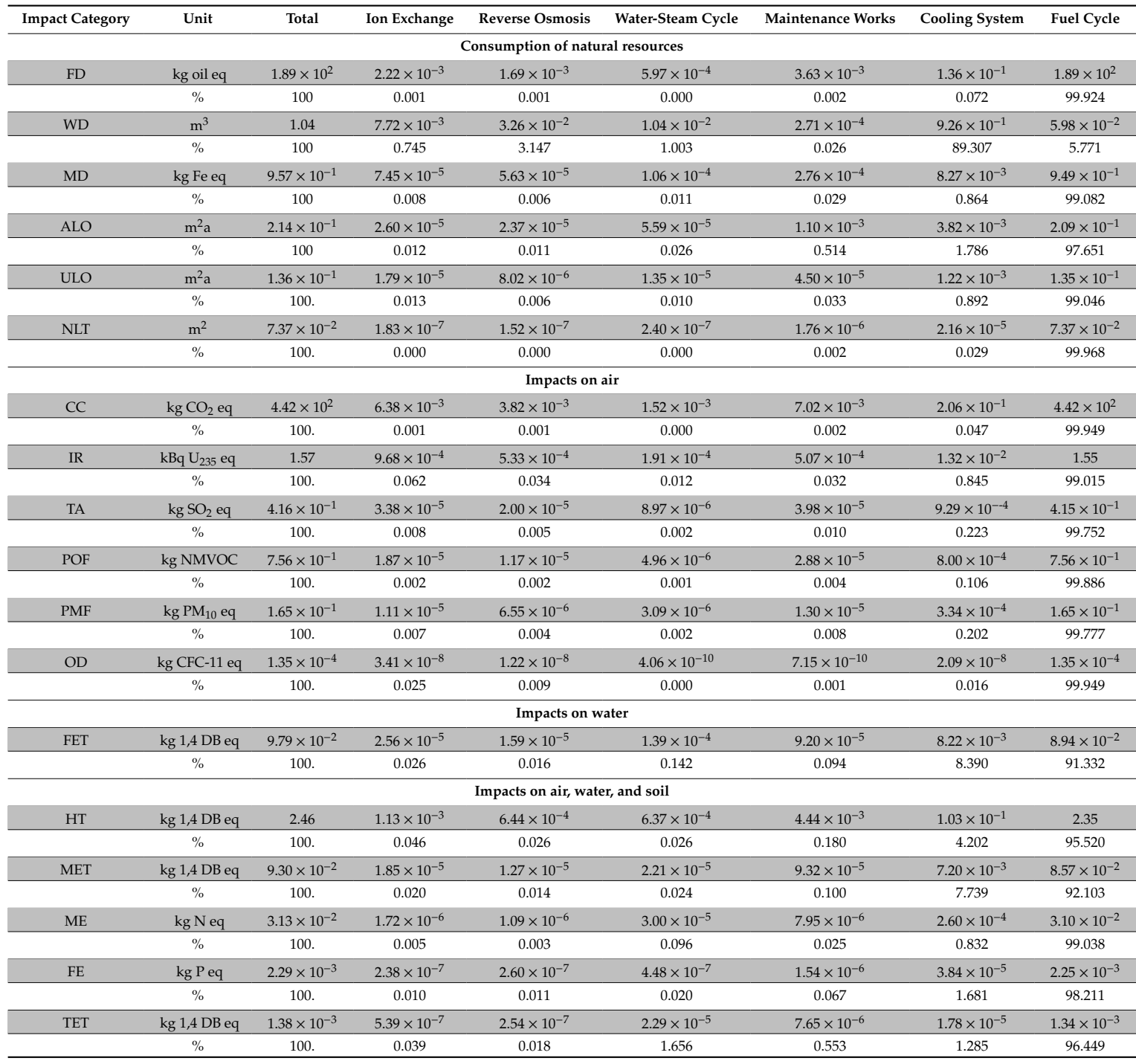

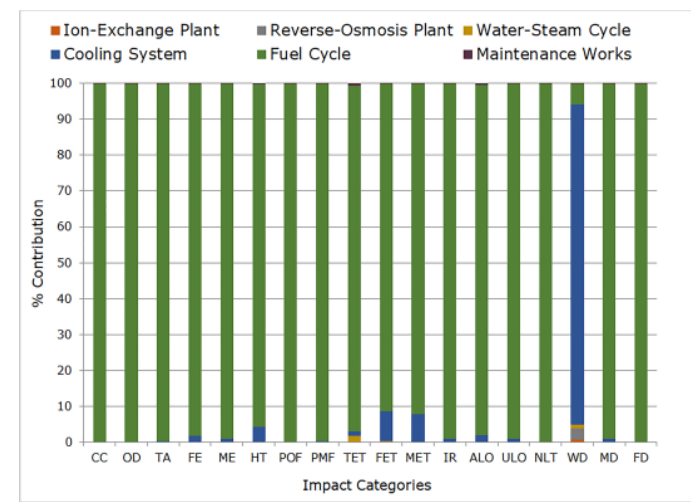

(a)

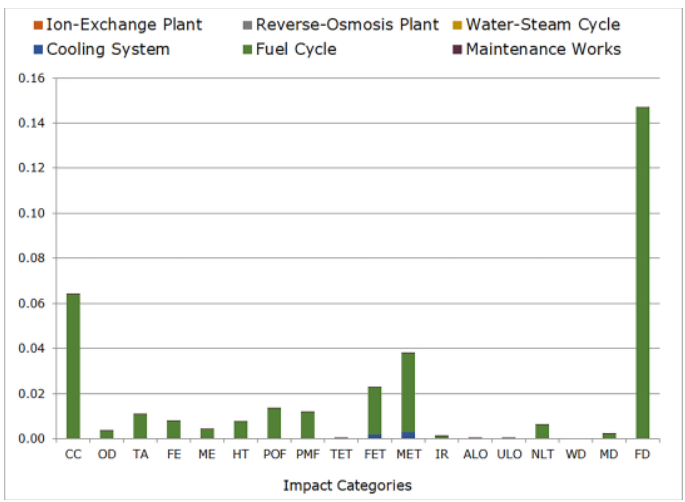

(b)

Figure 3. Contribution of all the stages to the impact categories: (a) characterization; (b) normalization.

After natural gas, the second most consumed natural resource during the process is water, which is mainly used in the cooling system. The total value in the WD category $\left(1.04 \mathrm{~m}^{3} / \mathrm{MWh}\right)$ is the net volume of water consumed resulting from the total volume of water extracted during the LCA $\left(1.53 \mathrm{~m}^{3} / \mathrm{MWh}\right)$ minus the total volume of water discharged $\left(0.49 \mathrm{~m}^{3} / \mathrm{MWh}\right)$. Less than $50 \%$ of the intake water is 
returned to the environment as wastewater discharge, which is considered an ecological flow; however, it is water that is polluted [35].

When the fuel-cycle values are not plotted on the graph, as shown in Figure 4a,b, it is possible to better appreciate the contributions of the other stages to each impact category. Now, the cooling system is the stage responsible for the highest impact, and even the lowest contributions made by the other stages can be seen.

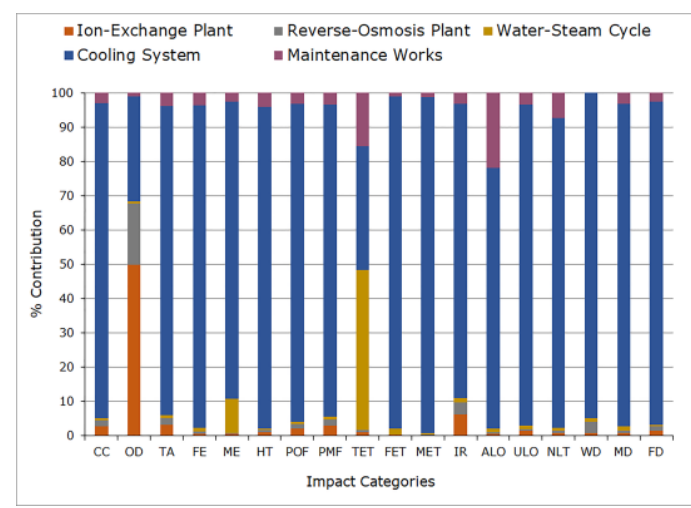

(a)

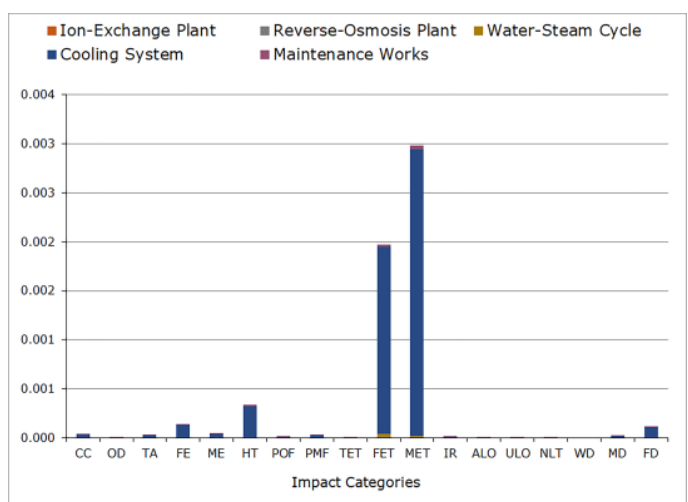

(b)

Figure 4. Contribution of the stages, excluding the fuel cycle, to the impact categories: (a) characterization; (b) normalization.

These contributions are, indeed, insignificant when compared to those of the fuel cycle. However, they are made by the stages to which chemicals-some of them toxic-are added. When considering the potential risks posed by chemicals, what seems negligible at first glance may not be so after a closer analysis.

Let's take, for example, cyclohexylamine. According to plant documents, on average, $1.85 \times 10^{-4} \mathrm{~kg}$ of this toxic substance is consumed per MWh for water conditioning. In 2016, CCGTs in Mexico produced 160,378 GWh of electricity [4], which, according to our calculations, resulted in an annual consumption of $30 \mathrm{t}$ of cyclohexylamine. By 2032, CCGTs are expected to generate $246,990 \mathrm{GWh}$ of electricity [4], which would require the consumption of approximately $46 \mathrm{t}$ of this substance for water conditioning in a year. This estimate is rather conservative, but it highlights the amount of just one toxic chemical that could potentially be released into the environment as wastewater discharges and only by one type of technology.

In the following subsections, the interpretation of the LCA results obtained for each one of the stages will be discussed.

\subsubsection{Cooling System}

Chemicals used for water conditioning, including all the resources needed for their manufacturing process and transportation, are the major causes of environmental impact.

Organic compounds such as microbiocides, corrosion anti-scale inhibitors, and bio-dispersants were not available in Ecoinvent; therefore, the "chemical production, organic" dataset was selected to evaluate the potential impact of the production of organic compounds.

$\mathrm{WD}$ is the most affected due to the high volume of water consumption $\left(0.95 \mathrm{~m}^{3} / \mathrm{MWh}\right)$.

FD is affected by the oil consumption during the manufacture of the organic compounds; $\mathrm{MD}$, by the use of copper in different forms for construction.

The manufacture of organic compounds has impacts on water and air. Impact categories related to water are FE, FET, and MET. Phosphates in waste contribute to FE; zinc discharges-which usually come from the galvanic industry, paints, and catalysts—affect FET and MET and have a cumulative effect on some organisms [36]. Barium discharges in water, which come from the material used in the oil and natural gas industry, contribute to $\mathrm{HT}$ [37]. The atmospheric impact is due to $\mathrm{CO}_{2}$ emissions 
from the ethylene production, which affects $\mathrm{CC}$; treatment of radioactive waste contributes to IR; $\mathrm{SO}_{2}$ in the natural gas production, to $\mathrm{TA}$; benzene coking with $\mathrm{SO}_{2}$, to PMF; $\mathrm{NO}_{x}$, to POF; and the emission of bromotrifluoromethane during the production of oil and natural gas contributes to OD.

ME is affected by nitrate discharges and $\mathrm{NO}_{x}$ atmospheric emissions; TET, by atmospheric emissions from acetic acid, bromine in water, and copper in soil from natural gas extraction.

The cooling system and the other stages that were evaluated (water-steam cycle, IX, RO, maintenance work, and fuel cycle) impacted in the same way the categories related to the occupation of natural areas: road and facilities construction contributed to NLT and ALO, and land used as a landfill had an impact on ULO.

Figure $5 \mathrm{a}$ shows the characterization results of the cooling system. After normalizing the results (see Figure 5b), the highest impacts were observed in MET, FET, and HT due to the discharges in water and the manufacture of chemical compounds (sodium hypochlorite and organic compounds).

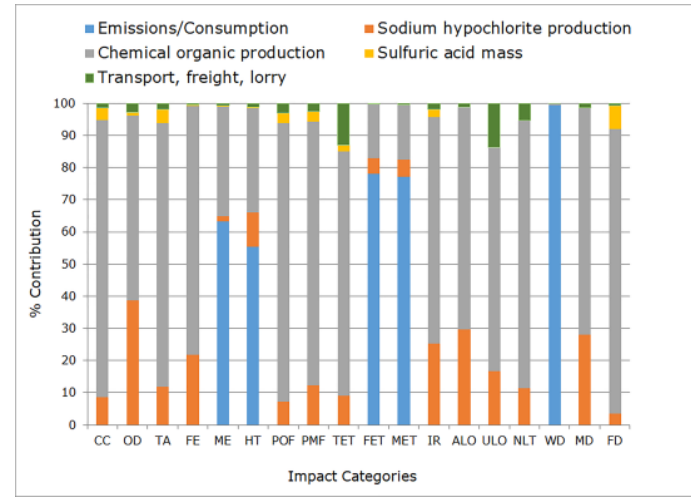

(a)

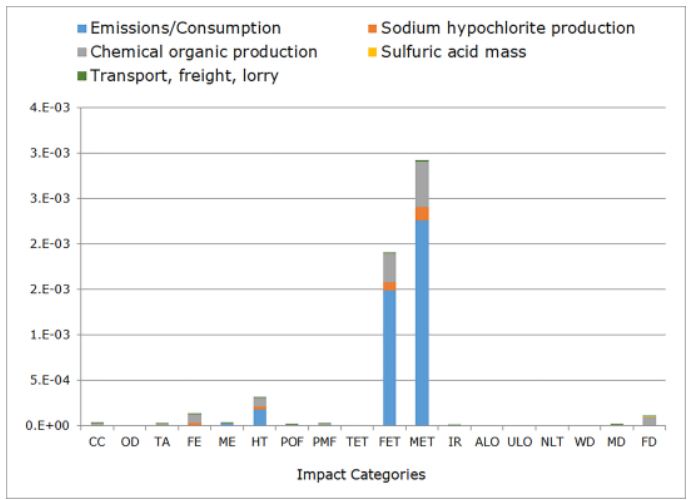

(b)

Figure 5. Contribution of materials and activities in the cooling system to the impact categories: (a) characterization; (b) normalization.

\subsubsection{Water-Steam Cycle}

As Figure 6a illustrates, the contribution of the manufacture and consumption of chemical compounds to most of the categories was high.

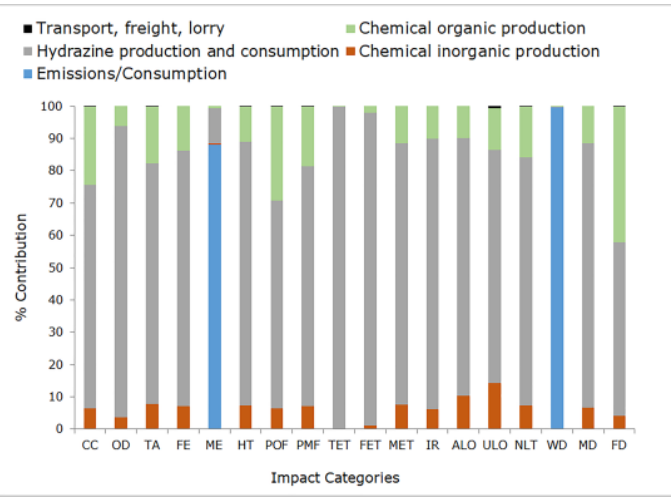

(a)

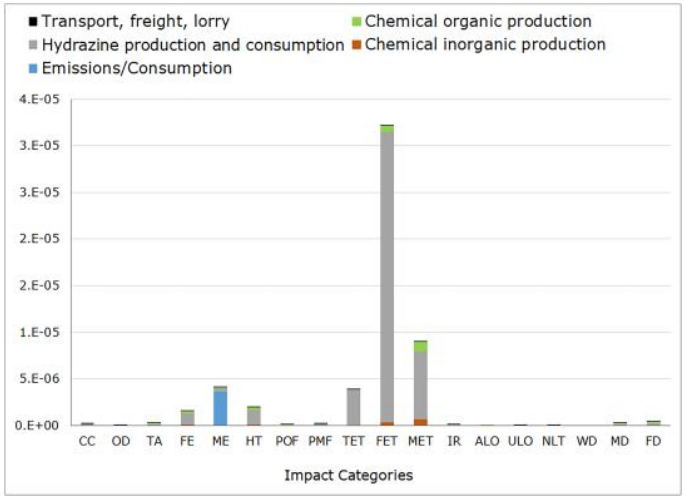

(b)

Figure 6. Contribution of the compounds used in the water-steam cycle: (a) characterization; (b) normalization.

Hydrazine is the compound with the highest impact on the environment due to its toxicity [38], which also poses a risk for handling and storage. Furthermore, during the hydrazine production process, $\mathrm{CO}_{2}$ emissions contribute to $\mathrm{CC}$; $\mathrm{SO}_{2}$, to TA and PMF; $\mathrm{NO}_{x}$, to POF; the use of copper, to $\mathrm{MD}$; phosphates, to $\mathrm{FE}$; treatment of radioactive waste, to IR; and natural gas consumption, 
to FD. A compound used in the production of hydrazine is chloramine, which is responsible for the contribution to TET (air emissions) and FET (air emissions and water discharges). MET is affected by copper in water and chlorine in the air; HT, by manganese in water and chlorine in the air; and ME, by nitrates.

Cyclohexylamine is a chemical compound that has a medium-low level of toxicity not only to humans, as it irritates the skin and mucous membranes, but also to aquatic organisms [39]. As this chemical is not included in the Ecoinvent database, the "chemical production, organic" dataset was selected to evaluate the impact of producing an organic chemical compound. Given the characteristics of this substance, if the model were available, the contribution to certain impact categories, especially those related to toxicity, could be higher.

Disodium and trisodium phosphates are toxic when ingested or inhaled and may irritate the skin, eyes, and the respiratory tract. The low-level toxicity of phosphates is due to their ability to sequester calcium [40]. These compounds were not included in the Ecoinvent database. To gain some insight about their potential impact, the "chemical production, inorganic" dataset was selected to evaluate the impact of producing an inorganic chemical compound.

The contribution to WD is due to demineralized water consumption $\left(0.0103 \mathrm{~m}^{3} / \mathrm{MWh}\right)$.

Normalized values are shown in Figure 6b. As can be seen, hydrazine production has a high impact on FET and a low impact on MET, TET and FE. Nitrate emissions are responsible for the contribution to ME.

\subsubsection{Demineralized Water Treatment and Maintenance Works}

The materials involved in each one of these stages are summarized in Figure 2 of Section 2.2.2.

IX Treatment

Of the demineralized water produced $\left(0.04 \mathrm{~m}^{3} / \mathrm{MWh}\right), 83 \%$ was obtained by RO; the rest, by IX.

In the IX treatment, the manufacture of anionic resins and $\mathrm{NaOH}$ made a high contribution to almost all the categories.

In the anionic resin manufacture, copper contributed to MD; bromine, to FET; tetrachloromethane in the air, to OD and HT-which was also affected by manganese discharges in water; copper in the air and in water contributed to MET; chlorine in the air and bromine in water, to TET; nitrate in water and $\mathrm{NO}_{x}$ in the air, to ME; and phosphates, to FE.

In the manufacture of $\mathrm{NaOH}, \mathrm{NO}_{2}$ contributed to POF; Cesium-137 discharged in water and Carbon-14 emitted into the air, to IR; $\mathrm{CO}_{2}$ emissions, to CC; and $\mathrm{SO}_{2}$ emissions, to TA and PMF.

FD was impacted by the fuel consumption in the sulfuric acid manufacture.

The effect on WD is caused by the amount of water extracted $\left(0.008 \mathrm{~m}^{3} / \mathrm{MWh}\right)$ to produce demineralized water, which is lower than the amount of water extracted for the treatment with RO.

\section{RO Treatment}

Regarding the RO treatment, the materials that caused the highest impact were water consumption and phosphonate used as an antifouling.

WD is affected by the water extracted $\left(0.056 \mathrm{~m}^{3} / \mathrm{MWh}\right)$ to produce demineralized water.

Phosphonate is not included in the Ecoinvent database; therefore, the "chemical production, organic" dataset was used to evaluate the potential environmental impact of the production of an organic compound.

In the organic production, the use of copper contributed to MD; crude oil extraction, to $\mathrm{FD} ; \mathrm{NO}_{2}$, to POF; copper emissions in water contributed to FET and MET; and nitrates in water and $\mathrm{NO}_{x}$ in the air had an impact on ME. Phosphates impacted FE; acetic acid emissions into the air, bromine discharges in water, and copper in soil contributed to TET.

In the anionic resin manufacture, tetrachloromethane in the air contributed to OD. 
The manufacturing process of $\mathrm{NaOH}$ affects IR, $\mathrm{CC}, \mathrm{TA}$, and PMF with the same substances that affect these categories in the IX treatment. In addition, mercury emissions into the air and manganese discharges in water contribute to HT.

\section{Maintenance Works}

More than 10 materials were used for the maintenance works model; however, only four of them had a markedly impact: cotton yarn waste, paint, white mineral oil, and hydraulic oil. The other materials considered made a low contribution (less than 5\%); thus, they are not mentioned.

The disposal of absorbent materials—-such as cotton yarn waste-impregnated with oil affects the soil; TET is affected by cypermethrin — an insecticide used to control moth pests of cotton.

In paint production, the use of metals—such as iron-contributes to $\mathrm{MD} ; \mathrm{SO}_{2}$ emissions, to PMF; the outflow of copper into water, to FET and MET; nitrates in water, to ME; and phosphates, to FE. NLT, ALO, and ULO are also affected.

In the production of white mineral oil, crude oil consumption contributed to $\mathrm{FD} ; \mathrm{SO}_{2}$ emissions, to $\mathrm{TA} ; \mathrm{NO}_{x}$, to POF; and barium discharges, to HT.

Hydraulic oil, evaluated within the "chemical production, organic" process contributes to CC due to $\mathrm{CO}_{2}$ emissions. In the manufacture of $\mathrm{NaClO}$, Radon-222 contributes to IR, and tetrachloromethane emissions into the air contribute to OD.

WD is affected by the water used in the manufacture of materials.

Figure $7 \mathrm{a}, \mathrm{b}$ show the results of characterization and normalization of the water treatment processes (IX and RO) and maintenance works.

After normalization, the categories that have a higher impact are FE, HT, FET, MET, and FD.

Anionic resin manufacture for the IX treatment, the organic compound production for $\mathrm{RO}$, and white mineral oil and paint production for maintenance works are responsible for the high contribution.

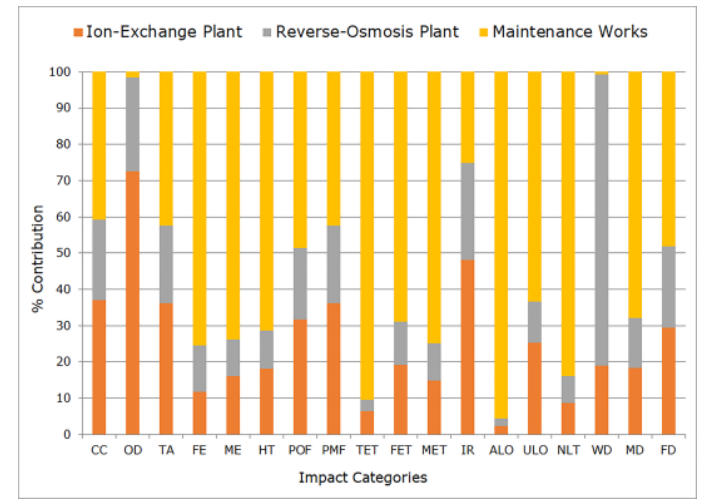

(a)

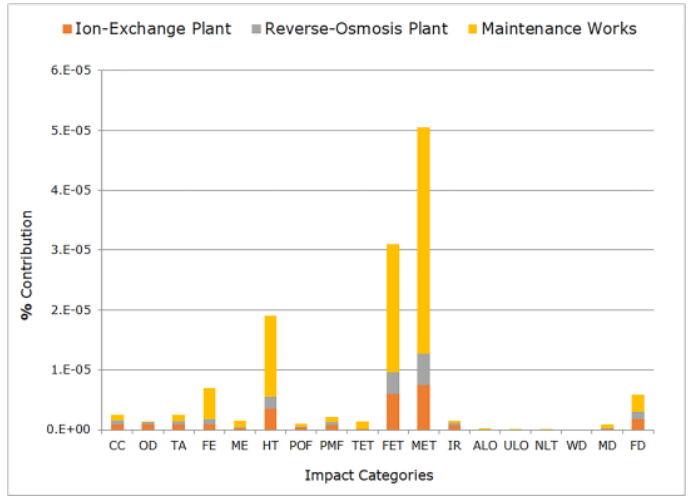

(b)

Figure 7. Contribution of maintenance works and the Ion Exchange and Reverse Osmosis plants to impact categories: (a) characterization; (b) normalization.

\subsubsection{Fuel Cycle}

The fuel cycle included three processes involving natural gas: extraction and production, processing and transportation, and combustion (emissions).

As Figure 8a illustrates, extraction and production of natural gas contribute to all the impact categories. The main impact is reflected in the depletion of natural resources: fossil-fuel (natural gas) consumption contributes to FD, and iron used for the infrastructure of natural gas extraction contributes to MD; WD is caused by water consumption for fuel extraction and processing and the manufacture of materials involved in these processes. Copper discharges in water affect FET, and copper atmospheric emissions and discharges in water impact MET. IR is affected by Carbon-14 from waste treatment, 
and bromotrifluoromethane affects OD. HT and TET are affected by mercury emissions into the air and barium in the soil caused by waste treatment. Mercury can also pollute drinking water or bioaccumulate in fish, affecting public health [8].

Regarding natural gas processing and transportation, ALO is impacted by the transformation of areas for new infrastructure; phosphate contribution to wastewater affects FE. Nitrates and phosphates in wastewater discharges cause eutrophication in bodies of water, resulting in the proliferation of algae and other plants, modifying the habitat for other organisms.

Natural gas combustion has a direct effect on the impact categories related to the emission of gases into the air: $\mathrm{CO}_{2}$ emissions affect $\mathrm{CC}$, and $\mathrm{NO}_{x}$ emissions contribute to TA, ME, POF, and PMF. $\mathrm{NO}_{x}$ and $\mathrm{CO}_{2}$ released during gas combustion affect human health and global warming. Regarding human health, short-term $\mathrm{NO}_{2}$ exposure can cause respiratory irritation and eye damage, whereas a long-term exposure can affect children's lungs and can cause chronic vascular brain disease and liver or spleen disorders. Elderly people, children, and people with health problems are the most vulnerable [41].

After normalizing the results, it can be seen that natural gas production has a high impact on FD, and it also has an effect on FET and MET. The combustion of natural gas affects CC, TA, POF, and PMF (see Figure 8b).

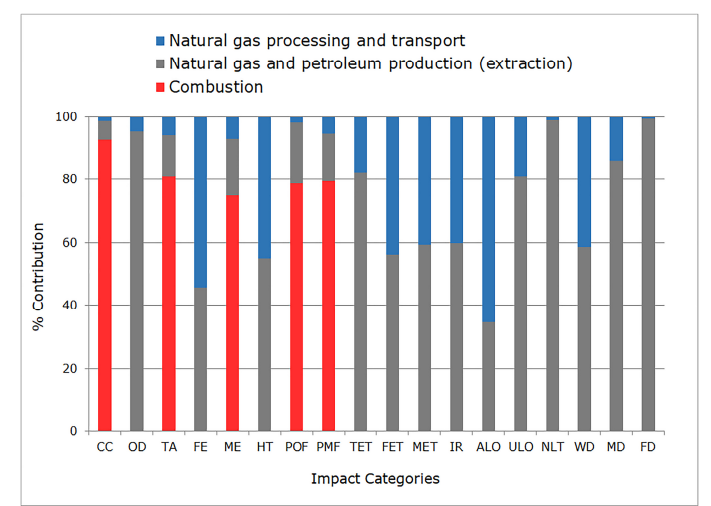

(a)

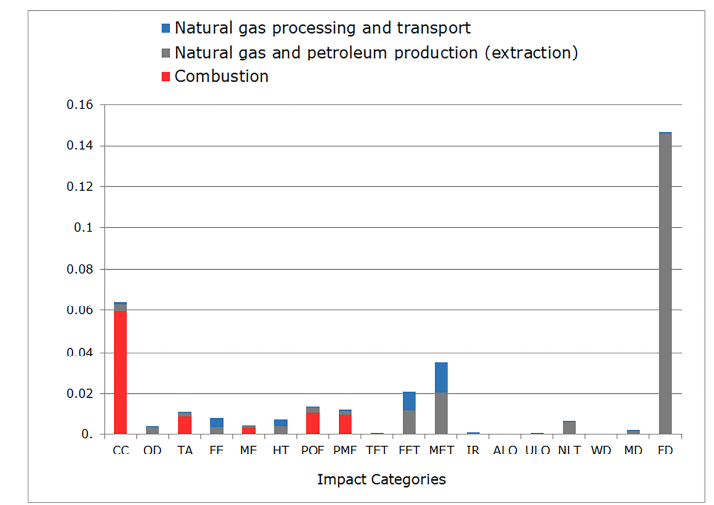

(b)

Figure 8. Contribution of the fuel cycle to impact categories: (a) characterization; (b) normalization.

\subsubsection{Comparison of the Results with Those of Similar Studies}

The methodology used in this research makes it possible to compare the overall CC and WD results of this study with the findings of similar LCA studies on electricity generation.

Table 5 shows a comparative analysis of the results of the contribution to CC.

The gas emitted during the electricity generation process is mainly $\mathrm{CO}_{2}$. Our result $(442.04$ $\mathrm{g} \mathrm{CO}_{2} \mathrm{eq} / \mathrm{kWh}$ ) is very close to that reported in Santoyo-Castelazo's study [14], and it is within the range of values found in Mertens et al. [19] for this technology, which gives us confidence in our methodology approach.

With regard to WD, it was only possible to compare the amount of water consumed in the cooling system with that reported by Mertens et al. [19]. These authors determined water consumption in four different CCGT plants, two of which use the same cooling system that is used in our case study. Their results show that the volume per kilowatt-hour of water extracted from seawater is higher than that from surface water.

In the present study, given the operating conditions of the plant and the source of water supply (well water), the volume of extraction is low because the volume of circulating water is higher in the cooling system. However, the water efficiency of the cooling tower is also low-two-thirds of the replacement volume is lost through evaporation, and one-third is lost in purges to keep salts under the saturation level [43]. 
Table 5. Comparative analysis of results of the contribution to the Climate Change category.

\begin{tabular}{|c|c|c|c|c|c|}
\hline \multirow{2}{*}{ Author } & \multirow{2}{*}{ Country } & \multirow{2}{*}{ Method } & \multirow{2}{*}{ Category } & Combustion Process & Fuel Cycle \\
\hline & & & & \multicolumn{2}{|c|}{$\left(\mathrm{g} \mathrm{CO}_{2} \mathrm{eq} / \mathrm{kWh}\right)$} \\
\hline $\begin{array}{l}\text { Spath and Mann } \\
\text { (2000) [18] }\end{array}$ & United States & $\begin{array}{c}\text { Tools for Environmental } \\
\text { Analysis } \\
\text { and Management } \\
\text { (TEAM) }\end{array}$ & GWP & 372.2 & 499.1 \\
\hline Hondo (2005) [12] & Japan & $\begin{array}{l}\text { Process analysis } \\
\text { and Input-output } \\
\text { analysis combined } \\
\text { method }\end{array}$ & GHG & 407.5 & 518.8 \\
\hline Weisser (2007) [42] & $\begin{array}{c}\text { Europe, North } \\
\text { America, and Japan }\end{array}$ & $\begin{array}{l}\text { Information from results } \\
\text { of recent GHG emission } \\
\text { life-cycle analysis }\end{array}$ & GHG & $360-575$ & - \\
\hline $\begin{array}{c}\text { Santoyo-Castelazo et al. } \\
\text { (2011) [14] }\end{array}$ & Mexico & CML & GWP & - & 446 \\
\hline Agrawal et al. (2014) [15] & India & CML 2001 & GWP & 471 & 584 \\
\hline Mertens et al. (2015) [19] & Europe & IPCC 2007 & GWP & & $415-460$ \\
\hline $\begin{array}{c}\text { Atilgan and Azapagic } \\
\text { (2016) [16] }\end{array}$ & Turkey & CML 2001 & GWP & & 499 \\
\hline $\begin{array}{l}\text { Ferat et al. } \\
\text { (present study) }\end{array}$ & Mexico & ReCiPe/CML & $\begin{array}{c}\text { Climate } \\
\text { Change/GWP }\end{array}$ & 410.35 & 442.04 \\
\hline
\end{tabular}

As a consequence of continuous evaporation, salt concentration increases. This fact and the continuous water reposition (to keep the volume constant), which contains its respective salts concentration, results in a continuous rise in the salinity that must be compensated with a correct regime of purges [44]. It is very probable that these discharges contain traces of additives-such as bio-dispersants, microbicides, and scale eliminators-added to condition the water and maintain the operation.

Table 6 shows the comparative analysis of water consumption and concentration factors between different water supply sources for the cooling system. The concentration factor corresponds to the ratio between the amount of extracted water and the amount of water discharged into a nearby body of water [19].

Table 6. Comparative analysis of water consumption and concentration factors between different water supply sources for the cooling system.

\begin{tabular}{|c|c|c|c|c|c|c|c|}
\hline $\begin{array}{l}\text { Water Supply } \\
\text { Source to CT }\end{array}$ & $\begin{array}{l}\text { Capacity } \\
\text { (MWe) }\end{array}$ & $\begin{array}{l}\text { Efficiency } \\
(\%)\end{array}$ & $\begin{array}{l}\text { Water in } \\
(\mathrm{L} / \mathrm{kWh})\end{array}$ & $\begin{array}{l}\text { Water out } \\
\text { (L/kWh) }\end{array}$ & $\begin{array}{l}\text { Conc. } \\
\text { Factor }\end{array}$ & $\begin{array}{c}\text { Consumed } \\
\text { Water }(\mathrm{L} / \mathrm{kWh})\end{array}$ & Ref. \\
\hline Surface CT & 437 & 55 & 2.9 & 1.5 & 1.95 & 1.4 & $\begin{array}{l}\text { Mertens et al. } \\
\text { (2015) [19] }\end{array}$ \\
\hline Water well CT & 265 & 53 & 1.4 & 0.44 & 3.1 & 0.95 & Present study \\
\hline
\end{tabular}

CT: Cooling Tower; MWe: Megawatt electric.

\subsection{Sensitivity Analysis Results}

\subsubsection{Changing the Water Treatment Process to Produce Demineralized Water}

Initially, two water treatment processes were in operation-IX and RO-but the possibility of using only one treatment was high because it is common practice in other plants using the same CCGT technology. The following three scenarios were proposed:

1. Base treatment: According to the volume of demineralized water produced in the month studied and the information obtained from plant documents, the LCA was performed considering that $17 \%$ of the volume produced was from IX and $83 \%$ from RO.

2. One month using only IX. 
3. One month using only RO.

As Figure 9 illustrates, using only the IX treatment has a substantial impact on almost all categories; however, the amount of water required is lower than the amount used with RO.

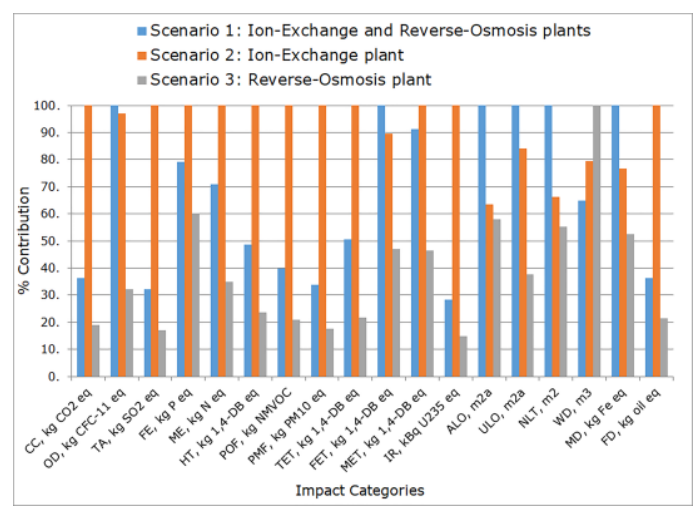

Figure 9. Sensitivity analysis: comparison of different water treatment processes.

Using only RO (scenario 3) is the best option if it is considered that its environmental impact is lower when compared with the other two scenarios; however, the contribution to WD is higher (a 20\% increase compared to using only IX and a 35\% increase compared to using the base treatment). This may be caused by the high volume of reject water and the water used to clean the membranes.

Identifying the best option is not an easy task; this will depend on the quality of the water entering the treatment system, the degree of purity and costs of the chemicals used in the treatment, the degree of cleanliness of the IX filters and/or of the RO membrane surface, and the energy consumption during operation, among other factors.

3.2.2. Using Only Hydrazine to Prevent Corrosion and Control the $\mathrm{pH}$ Level in the Boiler Feedwater Treatment during the Water-Steam Cycle

The plant under study uses two types of chemical compounds for corrosion and $\mathrm{pH}$ control in the boiler feedwater treatment: cyclohexylamine and hydrazine. Other CCGT plants use only hydrazine. The sensitivity analysis considered the following two scenarios:

1. Using two compounds: cyclohexylamine and hydrazine (our case study).

2. Using only one compound: hydrazine (data from another CCGT plant was used to calculate the amount of hydrazine considered to model this scenario).

The results in Figure 10 show that the impact of using only hydrazine (scenario two) is notably higher in almost all the impact categories except in FD. This could be explained by the fact that, in this scenario, cyclohexylamine is not included in the production of organic compounds, which decreases the use of fossil fuel.

Hydrazine has the advantage of not producing solids and favors the formation of a thin magnetite (ferrous ferric oxide) layer throughout the water-steam cycle, avoiding corrosion; however, both hydrazine and cyclohexylamine are toxic products. Interestingly, even though the combination of cyclohexylamine and hydrazine in the boiler feedwater treatment has an impact on all categories due to their toxicity, this impact is lower than that of using hydrazine alone. 


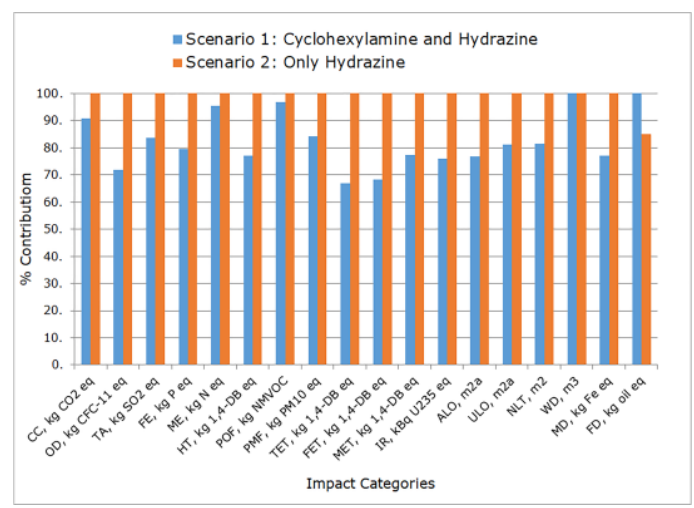

Figure 10. Comparison of the impacts caused by adding different compounds to the boiler feedwater treatment to prevent corrosion and control the $\mathrm{pH}$ level during the water-steam cycle.

\subsubsection{Presence of $d$-Limonene in the Water Discharged from the Cooling Tower}

Bio-dispersants are added to the cooling tower water to prevent the growth of Legionella bacteria. The plant in our case study uses orange terpenes, such as d-Limonene, to keep the heat exchanger equipment in cooling towers free from organic matter. D-Limonene belongs to the terpenoids family and is very efficient in removing biomass deposits caused by fast-growing microorganisms that attack metal surfaces [45].

However, exposure to d-Limonene and its oxidation byproducts over long periods, such as the time required for degreasing operations, can cause respiratory and skin irritations. Furthermore, d-Limonene is insoluble in water [46] and can bioaccumulate in fish and other aquatic organisms, making them toxic to other organisms that feed on them and to the ecosystems. With a newly proposed analytical method, it is possible to determine the presence of this compound in fish tissue at the laboratory for further studies [47]. In soil, the compound has little mobility; in the aquatic environment, it is expected to adsorb the sediment and organic matter in suspension [48].

The sensitivity analysis considered that this bio-dispersant is present in the wastewater discharge. This scenario was selected because, in a water quality analysis, it is not common to determine this type of compounds in wastewater discharges and, therefore, their environmental impact is unknown.

The concentration of d-Limonene in the wastewater discharge is a parameter that is not measured at the plant. Therefore, it was assumed that the amount present in the wastewater discharge would be the same amount added to the cooling tower water due to the compound's insolubility in water.

The results of the analysis, depicted in Figure 11, show that there is an increase of the pollutant in water, which is reflected only in three categories of toxicity: HT (17.48\%), FET (82.48\%), and MET $(0.83 \%)$. The rest of the categories were not affected.

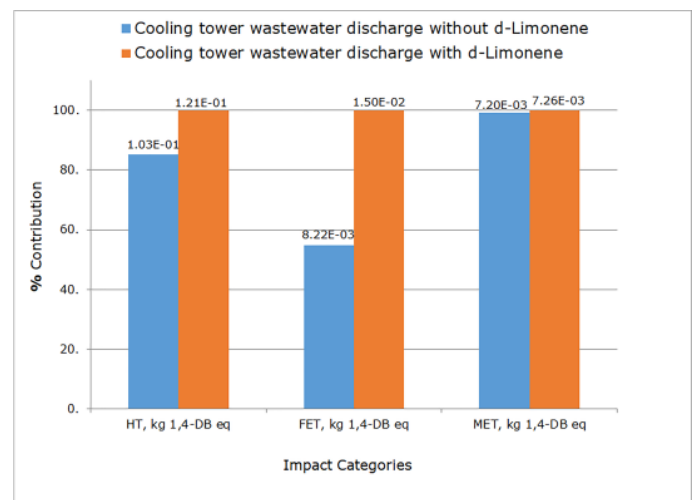

Figure 11. Comparison of the impacts caused by the presence or the absence of d-Limonene in the cooling tower wastewater discharge. 


\subsubsection{LCA Considering the Presence of D-Limonene in the Cooling Tower Wastewater Discharge}

An LCA of the electricity generation process was performed considering, this time, that the presence of d-Limonene in the cooling tower water discharge to see its effects. Then, the results of this analysis were compared to the LCA results obtained under the initial operating conditions (without d-Limonene).

Figure 12a shows that the impact of d-Limonene to HT, FET, and MET that had been detected in the sensitivity analysis is still present when considering the IX, RO, water-steam cycle, cooling system, and maintenance work stages in the evaluation of the electricity generation process.

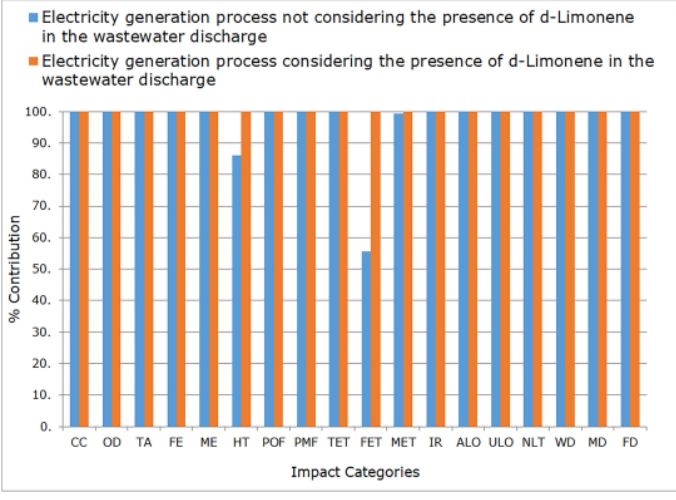

(a)

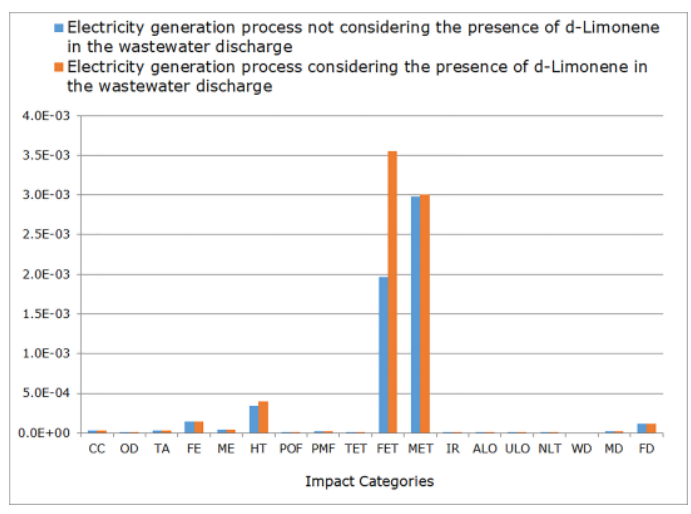

(b)

Figure 12. Life Cycle Assessment (LCA) of the electricity generation process considering initial operating conditions vs. considering also the presence of d-Limonene in the wastewater discharge: (a) characterization; (b) normalization.

After normalizing the results, it can be seen that the already high impact on HT, FET, and MET under the initial operating conditions is increased by the presence of d-Limonene (see Figure 12b).

\section{Conclusions}

An LCA of the electricity generation process was carried out to determine the environmental impacts of the chemicals used for water conditioning in a CCGT plant. The process was broken down into stages, which were analyzed separately. In each stage, the materials/processes that had the highest contribution to the impact categories were identified.

Our results showed that most affected categories were related to water and toxicity to the environment and living organisms. Water depletion $\left(9.77 \times 10^{-1} \mathrm{~m}^{3} / \mathrm{MWh}\right)$ was caused mainly by the high volume of water consumption in the cooling systems and the reverse osmosis process; ecotoxicity—freshwater $\left(8.49 \times 10^{-3} \mathrm{~kg}\right.$ 1,4-DB eq/MWh), marine $\left(7.35 \times 10^{-3} \mathrm{~kg}\right.$ 1,4-DB eq/MWh), and terrestrial $\left(4.92 \times 10^{-5} \mathrm{~kg} 1,4\right.$-DB eq/MWh)—and human toxicity $\left(1.1 \times 10^{-1} \mathrm{~kg} 1,4-\mathrm{DB}\right.$ eq/MWh $)$ were due to the manufacture and consumption of the chemicals used.

Not surprisingly, the high contribution of the fuel cycle overshadowed the contributions of the rest of the stages to the impact categories. However, these are the stages to which chemicals are added. Some of these substances are toxic to aquatic organisms. The effects of the likely presence of d-Limonene, a bio-dispersant, in the wastewater discharge were identified through a sensitivity analysis. The results showed that this chemical increases the already high contributions to human toxicity, freshwater and marine ecotoxicity. Unlike hydrazine, which is known for its adverse effects on the environment and has been identified as a pollutant, the rest of the organic compounds used for water conditioning could be considered as emerging pollutants. Further research should be done to investigate their effects as they could potentially leave traces in wastewater discharges.

It is essential to identify these toxic compounds and quantify their presence in the environment and living organisms to create models for assessing their impact. The lack of models for some chemicals made it difficult to obtain better results as the use of limited data provides only a rough estimate of 
the impacts. However, these first approximations can yield some insight into the potential effect of the compounds under study. By creating more robust databases, the results obtained by applying the LCA methodology would provide a more complete picture of the impact of these substances on the environment. Hence, the importance of this study is twofold: first, the data that was generated could contribute to the expansion of environmental datasets as the study was carried out in a Mexican power plant; and, second, this study identifies the effects of commonly-used chemicals in power plants-effects that, to our knowledge, have never been reported before.

This methodology approach, in conjunction with the block diagram proposed, could be applied to evaluate other electricity generation technologies and find better production alternatives that use less harmful chemicals for water conditioning, reduce environmental impacts, lower electricity generation costs, and make the processes more efficient. By fostering a closer link with academia, public and private sectors could work with researchers to align their work with these goals.

In addition, government authorities could use these results to define guidelines with stricter discharge parameters to be included in environmental assessments.

Furthermore, it is important to let consumers know about the environmental impacts that the electricity generation process causes and the close link between water and energy. In this way, a culture of electricity optimization and consumption can be encouraged to protect our environment, reducing the impact on climate change, water consumption, and toxicity to humans and other living organisms.

Water is essential for supporting life, and it is a key resource for economic development. The threat of water scarcity highlights the need for a more efficient and responsible water resource management to preserve the health of aquatic ecosystems, within a sustainability framework.

By 2032, the demand in Mexico for water and energy will increase, and the construction of CCGT plants will continue to grow because of their high efficiency. CCGTs are expected to generate 246,990 GWh of electricity, which would require, at least, a yearly consumption of approximately $46 \mathrm{t}$ of cyclohexylamine for water conditioning. This is just one of the many toxic chemicals used for this process by this type of technology.

For this reason, it is imperative to protect our water resources and implement new public policies aimed at achieving energy efficiency in the production and consumption of electricity and the development of innovative water-treatment technologies.

LCA, without a doubt, is a powerful tool. Even though it contains a particular value of uncertainty, this methodology helps to identify the potential environmental impacts, providing information that can be used as input for further research.

Author Contributions: C.F.T. designed and carried out the study and drafted the manuscript; C.M.-d.-C. supervised the application of the LCA to the case study and participated in the drafting of the manuscript; J.-L.F. provided the SimaPro software for the initial study trials, guidance on the LCA methodology, and advice on drafting the manuscript; G.M.-C. provided guidance on the chemicals (emerging compounds) used and their impact on the environment; G.L.d.l.S. was consulted on the plant structure and the realization of the mass and energy balance; and D.R.F. gave support in identifying the environmental impacts from a socio-economic point of view for economic valuation.

Funding: This research received no external funding.

Acknowledgments: We appreciate the support of the Comisión Federal de Electricidad (Federal Electricity Commission) for providing the means to make this study possible; Juan Pablo Chargoy A., MsChE, Director of Life Cycle Management of CADIS, for reviewing the results obtained from the LCA; and Mario Giraldi, PhD, for reviewing the data to perform the LCA.

Conflicts of Interest: The authors declare no conflict of interest. 


\section{Appendix A List of Acronyms, Initialisms, and Chemical Symbols}

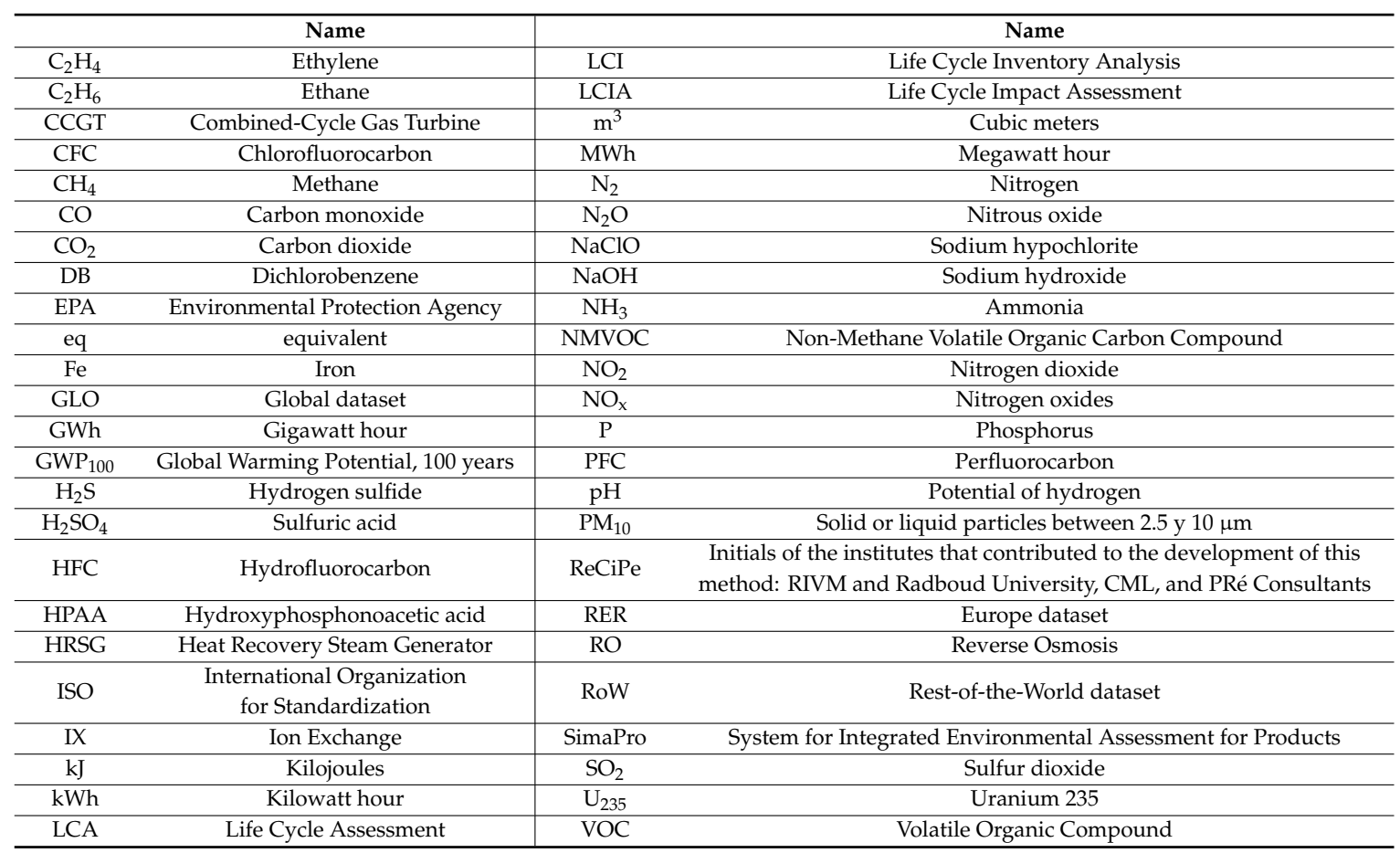

\section{References}

1. United Nations. Sostenibilidad del agua y la energía [Water and Energy Sustainability]. In Information Brief on 2014 UN-Water Annual International Zaragoza Conference. Preparing for World Water Day 2014: Partnerships for Improving Water and Energy Access, Efficiency and Sustainability, Zaragoza, Spain, 13-16 January 2014; Available online: http://www.un.org/spanish/waterforlifedecade/pdf/01_2014_sustainability_spa.pdf (accessed on 28 June 2017).

2. United Nations World Water Assessment Programme (WWAP). The United Nations World Water Development Report 2014; UNESCO: Paris, France, 2014; Volume 1: Water and Energy; Available online: http://unesdoc. unesco.org/images/0022/002257/225741E.pdf (accessed on 7 July 2017).

3. Mexico. Comisión Nacional del Agua (CONAGUA) [National Water Commission]. Estadísticas del agua en México, Edición 2017 [Statistics on Water in Mexico, 2017 Edition]. 2017. Available online: http://sina.conagua.gob.mx/ publicaciones/EAM_2017.pdf (accessed on 20 August 2018).

4. Mexico. Secretaría de Energía (SENER) [Ministry of Energy]. PRODESEN Programa de desarrollo del sistema eléctrico nacional 2018-2032 [National Electricity System Development Program, 2017-2032 Edition]. 2018. Available online: https:/www.gob.mx/cms/uploads/attachment/file/331770/PRODESEN-2018-2032definitiva.pdf (accessed on 11 March 2019).

5. García, S.; Ratia, P.; Perea, J. Operación y Mantenimiento de Centrales de Ciclo Combinado; Díaz de los Santos, Ed.: Madrid, Spain, 2008; pp. 183-194, 271-275. ISBN 978-84-7978-842-1.

6. Mexico. Comisión Federal de Electricidad (CFE) [Federal Electricity Commission]. Informe Annual 2014 [Annual Report 2014]. 2014. Available online: http://aplicaciones.cfe.gob.mx/Aplicaciones/OTROS/ InformeAnualConFirmas2014.pdf (accessed on 28 June 2017).

7. United Nations Environment Programme (UNEP). Global Chemicals Outlook-Towards Sound Management of Chemicals. 2013. Available online: https://www.unenvironment.org/explore-topics/chemicals-waste/ what-we-do/policy-and-governance/global-chemicals-outlook (accessed on 12 March 2019).

8. United States. Environmental Protection Agency. 40 CFR Part 423 Effluent Limitations Guidelines and Standards for the Steam Electric Power Generating Point Source Category; Final Rule, Part II. 2015. Available online: https://www.epa.gov/eg/steam-electric-power-generating-effluent-guidelines (accessed on 28 June 2017).

9. Mexico. Ministry of the Environment and Natural Resources (SEMARNAT). ORMA OFICIAL MEXICANA NOM-001-SEMARNAT-1996, que establece los límites máximos permisibles de contaminantes en las descargas 
de aguas residuales en aguas y bienes nacionales [Mexican Official Standard NOM-001-SEMARNAT-1996 That Establishes the Maximum Permissible Limits of Pollutants in Wastewater Discharges into National Waters and Resources]. 1996. Available online: http://www.conagua.gob.mx/CONAGUA07/Publicaciones/Publicaciones/ SGAA-15-13.pdf (accessed on 29 June 2017).

10. Becerril, B.E. Contaminantes emergentes en el agua. Rev. Digit. Univ. 2009, 10. Available online: http://www.revista.unam.mx/vol.10/num8/art54/int54.htm (accessed on 18 July 2017).

11. Van Hoof, B.; Monroy, N.; Saer, A. Producción más limpia. Paradigma de gestión ambiental; Alfaomega Grupo Editor: Mexico City, Mexico, 2008; ISBN 978-970-15-1367-5.

12. Hondo, H. Life Cycle GHG Emission Analysis of Power Generation Systems: Japanese Case. Energy 2005, 30, 2042-2056. [CrossRef]

13. Tan, R.B.H.; Wijaya, D.; Khoo, H.H. LCI (Life Cycle Inventory) Analysis of Fuels and Electricity Generation in Singapore. Energy 2010, 35, 4910-4916. [CrossRef]

14. Santoyo-Castelazo, E.; Gujba, A.; Azapagic, A. Life Cycle Assessment of Electricity Generation in Mexico. Energy 2011, 36, 1488-1499. [CrossRef]

15. Agrawal, K.K.; Jain, S.; Jain, A.; Dahiya, S. A Life Cycle Environmental Impact Assessment of Natural Gas Combined Cycle Thermal Power Plant in Andhra Pradesh, India. Environ. Dev. 2014, 11, 162-174. [CrossRef]

16. Atilgan, B.; Azapagic, A. Assessing the Environmental Sustainability of Electricity Generation in Turkey on a Life Cycle Basis. Energies 2016, 9, 31. [CrossRef]

17. Dinca, C.; Rousseaux, P.; Badea, A. A Life Cycle Impact of the Natural Gas Used in the Energy Sector in Romania. J. Clean. Prod. 2007, 15, 1451-1462. [CrossRef]

18. Spath, P.L.; Mann, M.K. Life Cycle Assessment of a Natural Gas Combined Cycle Power Generation System; National Renewable Energy Laboratory: Golden, CO, USA, 2000. Available online: https://www.nrel.gov/ docs/fy00osti/27715.pdf (accessed on 12 June 2014).

19. Mertens, J.; Prieur-Vernat, A.; Corbisier, D.; Favrot, E.; Boon, G.J. Water Footprinting of Electricity Generated by Combined Cycle Gas Turbines Using Different Cooling Technologies: A practitioner's experience. J. Clean. Prod. 2015, 86, 201-208. [CrossRef]

20. México. Instituto Mexicano de Normalización y Certificación (IMNC). Gestión Ambiental-Análisis de Ciclo de Vida-Principios y Marco de Referencia. Norma Mexicana IMNC: NMX-SAA-14040-IMNC-2008; Instituto Mexicano de Normalización y Certificación A.C.: Ciudad de México, Mexico, 2007.

21. México. Instituto Mexicano de Normalización y Certificación (IMNC). Gestión Ambiental-Análisis de Ciclo de Vida-Requisitos y directrices. Norma Mexicana IMNC: NMX-SAA-14044-IMNC-2008; Instituto Mexicano de Normalización y Certificación, A.C.: Ciudad de México, Mexico.

22. Selby, K.A.; Puckorius, P.R.; Helm, K.R. The Use of Reclaimed Water in Electric Power Stations and Other Industrial Facilities. Water Air Soil Pollut. 1996, 90, 183-193. [CrossRef]

23. Guinée, J.B.; Gorrée, M.; Heijungs, R.; Huppes, G.; Kleijn, R.; de Koning, A.; van Oers, L.; Wegener Sleeswijk, A.; Suh, S.; Udo de Haes, H. Handbook on Life Cycle Assessment. Operational Guide to the ISO Standards; Kluwer Academic Publishers: Dordrecht, The Netherlands, 2002; ISBN 978-0-306-48055-3.

24. Swiss Centre for Life Cycle Inventories. Life Cycle Inventories of Chemicals. 2007. Available online: https://db.ecoinvent.org/reports/08_Chemicals.pdf (accessed on 3 March 2017).

25. United Nations Environment Programme (UNEP)/Society of Environmental Toxicology and Chemistry (SETAC). USEtox. Available online: https://www.usetox.org/ (accessed on 30 October 2016).

26. Environmental Protection Agency. Natural Gas Combustion. In AP42, Fifth Edition Compilation of Air Pollutant Emissions Factors: Stationary Points and Area Sources; EPA: Washington, DC, USA, 1998; Volume 1. Available online: https:/www.epa.gov/air-emissions-factors-and-quantification/ap-42-compilation-airemissions-factors\#5thed (accessed on 5 April 2015).

27. Thermoflow Inc. Thermoflex (Version 25.0) [Computer Software]. Thermoflow Inc.: Jacksonville, FL, USA, 2017. Available online: https://www.thermoflow.com/products_overview.html\# (accessed on 10 February 2017).

28. Universidad Autónoma de Tamaulipas (UAT). Manifiesto de Impacto Ambiental. Modalidad Particular. Ciclo combinado Agua Prieta II. Available online: http://sinat.semarnat.gob.mx/dgiraDocs/documentos/son/ estudios/2003/26SO2003E0018.pdf (accessed on 25 October 2015).

29. Mexico. Comisión Federal de Electricidad (CFE). Informe preventivo de impacto ambiental para la instalación y operación de la Unidad Turbogás El Sauz, a ubicarse en el estado de Querétaro, México. 1997. 
Available online: http://sinat.semarnat.gob.mx/dgiraDocs/documentos/qro/estudios/1997/22QE97E0009.pdf (accessed on 11 November 2014).

30. Mexico. Instituto de Ecología (IE); Comisión Federal de Electricidad (CFE). Manifiesto de impacto ambiental. Modalidad particular. Unidad Turbogás San Lorenzo, Puebla. 2003. Available online: http://sinat.semarnat. gob.mx/dgiraDocs/documentos/pue/estudios/2003/21PU2003E0001.pdf (accessed on 26 June 2015).

31. PRé Consultants B.V. SimaPro (Version 8.0.4.30) [Computer Software]. Pré Sustainability: Amersfoort, The Netherlands, 2014. Available online: https://simapro.com (accessed on 10 October 2017).

32. Goedkoop, M.; Heijungs, R.; Huijbregts, M.; De Schryver, A.; Struijs, J.; van Zelm, R. ReCiPe 2008. A Life Cycle Impact Assessment Method Which Comprises Harmonised Category Indicators at the Midpoint and the Endpoint Level. Report I: Characterisation, First, 2013. Ministerie van VROM. Available online: https://www.pre-sustainability.com/ download/ReCiPe_main_report_MAY_2013.pdf (accessed on 14 May 2015).

33. PRé Consultants. SimaPro Database Manual Methods Library; SimaPro: Amersfoort, The Netherlands, 2014.

34. United States. US Environmental Protection Agency. Life Cycle Assessment: Principles and Practice. 2006. Available online: https://nepis.epa.gov/Exe/ZyPDF.cgi/P1000L86.PDF?Dockey=P1000L86.PDF (accessed on 24 July 2018).

35. Buecker, B. Wastewater Treatment Issues for Combined Cycle Plants, 2014. Power Engineering. Available online: https://www.power-eng.com/articles/print/volume-118/issue-4/features/wastewatertreatment-issues-for-combined-cycle-plants.html (accessed on 2 April 2016).

36. Lenntech B.V. Cinc y Agua: Mecanismos de Reacción, Impacto Ambiental y Efectos en la Salud. Available online: http://www.lenntech.es/cinc-y-agua.htm (accessed on 12 July 2017).

37. Estrucplan. Bario. Available online: http://www.estrucplan.com.ar/Producciones/entrega.asp?IdEntrega= 1018 (accessed on 12 July 2011).

38. Hydrazine Sulfate; Acros Organics. Available online: https://www.fishersci.es/chemicalProductData_uk/ wercs?item Code $=10117383 \&$ lang=ES (accessed on October 2018).

39. Ciclohexilamina; Hoja de Seguridad (30126992/SDS_GEN_MX/ES); Badische Anilin-und Soda-Fabrik (BASF) Mexicana, SA de CV, 21 September 2015. Available online: https://worldaccount.basf.com/wa/NAFTA \{\}en_US/Catalog/ WaterSolutions/doc4/BASF/PRD/30126992/.pdf?asset_type=msds/pdf\&language=ES\&validArea=MX\&urn=urn: documentum:ProductBase_EU:09007af880382acf.pdf (accessed on 29 December 2016).

40. Fosfato disódico y trisódico; Hojas de Seguridad; Industrias EMU, S.A. Available online: http://www. industriasemu.com/EMU_soluciones_agroindustriales_home_esp.asp (accessed on 19 December 2016).

41. Ministerio de Agricultura y Pesca, Alimentación y Medio Ambiente (MAPAMA). Óxidos de Nitrógeno. Available online: http:/www.mapama.gob.es/es/calidad-y-evaluacion-ambiental/temas/atmosfera-y-calidad-del-aire/ calidad-del-aire/salud/oxidos-nitrogeno.aspx (accessed on 9 July 2017).

42. Weisser, D. A Guide to Life-Cycle Greenhouse Gas (GHG) Emissions from Electric Supply Technologies. Energy 2007, 32, 1543-1559. [CrossRef]

43. Sax, N.I. Industrial Pollution; Van Nostrand Reinhold Company: New York, NY, USA, 1974; p. 187. ISBN 0-442-27366-5.

44. Marcó, J. Tratamiento de agua en torres de enfriamiento. Prevención de Legionella. Energuía 2001, 81-87. Available online: https:/es.slideshare.net/testgrupocomex/tratamientos-del-agua-en-torres-de-refrigeracin (accessed on 2 August 2017).

45. Saavedra, P.; Hernández, M.; León, D. Evaluación de la eficacia de diferentes dispersantes para controlar el ensuciamento en sistema de enfriamiento de agua. Tecnol. Ciencia 2005, 20, 5-10.

46. The Royal Society of Chemistry. ChemSpider: Search and Share Chemistry; CAS (138-86-3) ( \pm ) -Limonene. Available online: http://www.chemspider.com/Chemical-Structure.20939.html (accessed on 14 July 2017).

47. Chen, C.L.; Löfstrand, K.; Adolfsson-Erici, M.; MacLeod, M. Determination of Fragrance Ingredients in Fish by Ultrasound-Assisted Extraction Followed by Purge \& Trap. Anal. Methods 2017, 9, 2237.

48. World Health Organization (WHO). Concise International Chemical Assessment Document 5. Limonene. 1998. Biblioteca virtual de desarrollo sostenible y salud ambiental. Available online: http://www.bvsde.paho. org/bvstox/i/fulltext/limonene/limonene.pdf (accessed on 14 July 2017).

(C) 2019 by the authors. Licensee MDPI, Basel, Switzerland. This article is an open access article distributed under the terms and conditions of the Creative Commons Attribution (CC BY) license (http://creativecommons.org/licenses/by/4.0/). 